\title{
Alvin Plantinga
}

\section{Naturalizm metodologiczny?*}

Dzieło św. Augustyna De Civitas Dei, napisane z niezrównanym rozmachem i elokwencją, jest wspaniałym wyrazem przyjętej przez rzesze późniejszych chrześcijan wizji historii człowieka. ${ }^{1}$ Zgodnie z tą wizją dzieje człowieka są historią zmagań, rywalizacji, walki, w której jedną ze stron jest, jak je określił Augustyn, Civitas Dei, Miasto Boże, drugą zaś - Miasto Doczesne albo Miasto Człowieka. Pierwsze poświęcone jest oddawaniu czci i służbie Panu; drugie natomiast służy zupełnie innemu władcy. Augustyn sądzi, że całą historię człowieka należy pojmować $\mathrm{z}$ punktu widzenia tych zmagań oraz że niemal każde przedsięwzięcie kulturowe, niezależnie od jego wielkości czy znaczenia, jest z nimi nierozerwalnie związane. Współcześnie nauka stanowi niezmiernie ważny aspekt życia intelektualnego. Oczywiście są tacy, którzy nie dostrzegają w niej nic prócz technologii, nic ponad środki do zaspokajania celów praktycznych, takich jak zwalczanie chorób i budowanie mostów lub pojazdów kosmicznych. Niewątpliwie są jednak w błędzie. Nauka rzeczywiście dokonała tych ważnych rzeczy, ale osiągnęła także coś więcej: dała nam dogłębny wgląd w nas samych i świat stworzony przez Boga. Odmieniła nasz intelektualny krajobraz. Trudno sobie nawet wyobrazić, jak wyglądałoby bez niej nasze życie intelek-

\footnotetext{
*Alvin Plantinga, „Methodological Naturalism?”, w: Jitse M. van der Meer (ed.), Facets of Faith and Science: Volume 1: Historiography and Modes of Interaction, The Pascal Centre for Advanced Studies in Faith and Science \& University Press of America, Inc., Lanham - New York - London 1996, s. 177-221. Za zgodą Autora oraz Wydawców z języka angielskiego przełożył: Radosław Plato.

${ }^{1}$ Przykładowo wielu chrześcijan reformowanych za Abrahamem Kuyperem utrzymuje, że działalność intelektualna w ogóle, a nauki przyrodnicze w szczególności, nie są wolne od zaangażowania religijnego. Być może zasługę za tę ideę powinno się przypisać nie Augustynowi, lecz Tertulianowi. O tym ostatnim krąż̇ły niepochlebne opinie, jednakże podkreślał on, że nauka działalność intelektualna — nie jest religijnie neutralna.
} 
tualne. Jeśli podążymy za Augustynem, powinniśmy przeto oczekiwać, że nauka także odgrywa ważną rolę w opisywanych przezeń zmaganiach.

Jednakże wedle idei bardzo popularnej od czasów Oświecenia nauka (przynajmniej ta uprawiana jak należy) stanowi chłodną, racjonalną, całkowicie bezstronną ${ }^{2}$ próbę dociekania prawdy o nas i naszym świecie, całkowicie wolną od ideologii, przekonan moralnych czy religijnego lub teologicznego zaangażowania. Oczywiście na tym obrazie ostatnio pojawiły się pewne pęknięcia. Warto jednak zauważyć, że szesnaście wieków temu Augustyn dostarczył racji na rzecz tezy, iż to pospolite przekonanie nie może być słuszne. Zbytnią naiwnością byłoby myślenie, że współczesna nauka jest religijnie i teologicznie neutralna, stoi beztrosko ponad tą augustiańską walką i nie odgrywa w niej żadnej roli. To może być prawdą w odniesieniu do pewnych części nauki: zagadnienia, takie jak wielkość i kształt Ziemi oraz jej odległość od Słońca, układ okresowy pierwiastków, dowód twierdzenia Pitagorasa, są w praktycznym sensie religijnie neutralne. Ale wiele innych obszarów nauki pod tym względem bardzo się od nich różni. W sposób ewidentny i zasadniczy uczestniczą one w starciu przeciwstawnych światopoglądów. Nie ma żadnej jasnej reguły orzekania, które części nauki są neutralne względem tego konfliktu, a które - nie. Oczywiście mamy tu do czynienia raczej z kontinuum niż jakimś prostym rozróżnieniem. Obowiązuje tu jednak pewna robocza, niepisana zasada: znaczenie określonego obszaru nauki dla tego konfliktu zależy od tego, jak dalece ten obszar zaangażowany jest w próbę zrozumienia nas samych jako ludzi. Możliwe, że występuje tu jeszcze inna zmienna: w jakim stopniu ten obszar jest „teoretyczny”, w sensie bycia nakierowanym na zrozumienie, nie zaś na opanowanie przyrody?

Bardzo interesujące byłoby dalsze zgłębienie tego zagadnienia, gdyż umożliwiłoby to dokładniejsze ustalenie, co rozumiem przez to, że nauka nie jest religijnie neutralna, oraz na jakie dokładnie sposoby chrześcijaństwo rzutuje na pojmowanie i aspekty praktyczne licznych istotnie różniących się od siebie nauk oraz części nauki. Pierwsze zagadnienie nie jest jednak przedmiotem zainteresowania tego artykułu, drugie wymaga zaś (oczywiście) bez porównania większej

\footnotetext{
${ }^{2}$ Naturalnie nie chodzi o to, żeby naukowiec nie pasjonował się nauką jako taką, ulubionymi teoriami albo swoją reputacją. Chodzi natomiast o to, że żaden z tych czynników nie wpływa na właściwą ocenę teorii naukowej lub wyjaśnienia.
} 
wiedzy na temat nauki niż jestem w stanie opanować. To problem ważki nie tylko dla filozofów, lecz także dla współpracującej ze sobą chrześcijańskiej wspólnoty naukowców i filozofów. Mój artykuł ma zaś charakter zdecydowanie bardziej programowy. Najpierw przytoczę trzy przykłady religijnej nieneutralności twierdzeń lub hipotez naukowych. Następnie będę argumentował, że chrześcijańska wspólnota akademicka i naukowa powinna uprawiać naukę na swój własny sposób, wychodząc od przyjęcia za pewnik tego, co wiemy jako chrześcijanie. (Poważnym mankamentem tej sugestii jest to, że obecnie jest równie niepopularna, jak heretycka. Będę jednak argumentował, że ma ona również niewątpliwą wartość - jest bowiem słuszna.) Jeden z zarzutów wobec tej sugestii jest uświęcony dictum, że warunkiem koniecznym należycie uprawianej nauki jest „naturalizm metodologiczny” lub (jak określa go Basil Willey) ,prowizoryczny ateizm". ${ }^{3}$ Owo dictum to idea, że nauka, we właściwym jej rozumieniu, musi być wolna od przekonań bądź zaangażowań religijnych. Moim głównym celem $\mathrm{w}$ niniejszym artykule jest zgłębienie, zrozumienie, omówienie i ocena tego twierdzenia oraz argumentów na jego rzecz. Jestem aż nadto świadom, że to, co mam do powiedzenia, ma charakter wstępny oraz niepełny, a więc nie różni się zbytnio od szeregu sugestii dla programów badawczych w filozofii chrześcijańskiej.

\section{Czy nauka jest religijnie neutralna? Trzy przykłady}

\section{Simon i altruizm}

Rozważmy najpierw pewne przykłady sugerujące, zupełnie niezależnie od szerszych augustiańskich rozważań, ${ }^{4}$ że nauka nie jest religijnie neutralna. Roz-

\footnotetext{
${ }^{3}$ „Nauka musi mieć prowizorycznie ateistyczny charakter albo przestaje być nauką” (Basil Willey, „Darwin's Place in the History of Thought”, w: Michael Banton (ed.), Darwinism and the Study of Society: A Centenary Symposium, Quadrangle Books, Chicago 1961, s. 1-16). Oczywiście Willey nie twierdził, że tych, którzy postępują w ten sposób, należy oskarżać o ate izm. Tym samym z nazwania tej procedury czy zakazu „,naturalizmem metodologicznym” nie wynika, że ci, którzy postępują w ten sposób, naprawdę są naturalistami (por. Ernan McMuluin, „Plantinga's Defense of Special Creation”, Christian Scholar's Review 1991, vol. 21, no. 1, s. 57 [55-79]).

${ }^{4}$ Wstępną próbę zgłębienia niektórych spośród tych rozważań podjąłem w artykułach: „When Faith and Reason Clash: Evolution and the Bible”, Christian Scholar's Review 1991,
} 
pocznę od opublikowanego względnie niedawno artykułu Herberta Simona. ${ }^{5}$ Artykuł ten dotyczy problemu altruizmu. Dlaczego, pyta Simon, tacy ludzie jak Matka Teresa, szkocki misjonarz Eric Liddell, Małe Siostry od Ubogich, misjonarze jezuiccy w siedemnastym wieku albo misjonarze metodyści w dziewiętnastym robią to, co robią? Dlaczego poświęcają swój czas i energię, a nawet całe życie dla dobra innych? Naturalnie nie tylko wielcy święci tego świata przejawiają ten odruch. Większość $\mathrm{z}$ nas przejawia go w takim czy innym stopniu. Przeznaczamy pieniądze, by zapewnić ubranie i żywność ludziom, których nigdy nie spotkaliśmy. Możemy wspierać misjonarzy w obcych krajach. Staramy się, nawet jeśli nieodpowiedzialnie i po omacku, robić, co tylko możemy, aby pomóc wdowom i sierotom.

Zatem jak, zapytuje Simon, możemy wyjaśnić zachowanie tego rodzaju? Twierdzi on, że zachowanie racjonalne polega na działaniu lub próbie działania w taki sposób, który zwiększa moje własne przystosowanie (fitness), to jest takim działaniu, które zwiększa prawdopodobieństwo, że moje geny szeroko rozprzestrzenią się w następnym i dalszych pokoleniach, a zatem które pozwala dobrze radzić sobie $\mathrm{w}$ derbach ewolucji. ${ }^{6} \mathrm{O}$ pewnym, tak pojmowanym, paradygmacie racjonalnego zachowania doniosła South Bend Tribune: „Cecil B. Jacobson, specjalista w leczeniu bezpłodności, został oskarżony o użycie własnej spermy do zapładniania swoich pacjentek. Możliwe, że jest ojcem co najmniej 75 dzieci — poinformował w piątek prokurator". ${ }^{7}$ Jednakże, w przeciwieństwie

vol. 21, no. 1, s. 8-33; „Evolution, Neutrality, and Antecedent Probability: A Reply to Pun, Van Till and McMullin”, Christian Scholar's Review 1991, vol. 21, no. 1, s. 80-109; oraz w książce: The Twin Pillars of Christian Scholarship: The Henry Stob Lectures, Calvin College and Seminary, Grand Rapids 1989.

${ }^{5}$ Herbert A. Simon, „A Mechanism for Social Selection and Successful Altruism”, Science 1990, vol. 250, no. 4988, s. 1665-1668. Simon został laureatem Nagrody Nobla w dziedzinie ekonomii, ale obecnie jest profesorem informatyki i psychologii w Carnegie-Mellon University.

${ }^{6}$ Ujmując rzecz prościej, Simon powiada, że ,przystosowanie oznacza po prostu oczekiwaną liczbę potomstwa” (Simon, „A Mechanism...”, s. 1665). Stwierdzenie, że na tym polega racjonalna droga kierowania własnym życiem, z jakiegoś powodu uznaje się za konsekwencję teorii ewolucji. Lecz nawet jeśli teoria ewolucji jest prawdziwa, to czy rzeczywiście wynika z niej ta rzekoma konsekwencja? Być może posiadanie dużej liczby potomstwa jest w pewien sposób najlepsze dla moich genów, ale dlaczego powinienem być tym szczególnie zainteresowany? Czyż nie byłoby rozsądniej skupić się na moim dobru, nie ich?

${ }^{7}$ South Bend Tribune 21 December 1991; nagłówek Alexandria, Virginia. 
do Jacobsona, ludzie tacy jak Matka Teresa i Tomasz z Akwinu niefrasobliwie lekceważą krótko- i długoterminowy los swoich genów. Na czym polega wyjaśnienie ich zachowania?

Simon twierdzi, że odpowiedź zasadza się na dwóch mechanizmach: „uległości” * oraz „racjonalności ograniczonej”:

Osoby uległe przejawiają tendencję do uczenia się i dawania wiary temu, czego w ich mniemaniu oczekują od nich inni członkowie społeczeństwa. Dlatego treść przyswajanej wiedzy nie będzie w pełni przekładać się na ich własne przystosowanie. ${ }^{8}$

Ze względu na swoją ograniczoną racjonalność jednostka uległa często nie będzie zdolna do odróżnienia zachowań zalecanych społecznie, które przyczyniają się do jej przystosowania, od zachowań altruistycznych [to jest zachowań społecznie zalecanych, które nie przyczyniają się do ich własnego przystosowania - A.P.]. W istocie uległość osłabia zdolność niezależnej oceny tego, czy określone zachowanie przyczynia się do przystosowania [...]. Ze względu na ograniczoną racjonalność osoby uległe nie mogą przyswoić wiedzy i umiejętności korzystnych dla siebie, które zapewniają wzrost, $d$, przystosowania bez przyswajania również zachowań altruistycznych, które prowadzą do spadku przystosowania, $c{ }^{9}$

\footnotetext{
* (Przyp. tłum.) Simon podkreślał, że terminem „uległość” (docility) posługuje się zasadniczo w słownikowym znaczeniu: „skłonność do uczenia się od innych”, a ściślej: „podatność na wpływy społeczne” (por. Sімоn, „A Mechanism...”, s. 1665, 1666).

${ }^{8}$ Simon, „A Mechanism...”, s. 1666.

${ }^{9}$ Simon, ,A Mechanism...”, s. 1667.

(Przyp. tłum.) W cytowanym artykule Simon sformułował matematyczny model zachowań altruistycznych, uwzględniający mechanizm społecznego zdobywania wiedzy. W ramach modelu porównanie przystosowania (wyrażonego w przeciętnej liczbie potomstwa) jednostek altruistycznych $\left(F_{\mathrm{A}}\right)$ i samolubnych $\left(F_{\mathrm{S}}\right)$ wyraża się wzorami: $F_{\mathrm{A}}=X+d-c+b(c) p$ oraz $F_{\mathrm{S}}=X+b(c) p$, gdzie $X$ oznacza liczbę potomstwa pod nieobecność zachowań altruistycznych; $d$ - przyrost brutto liczby potomstwa A dzięki jej uległości; $c$ — koszt netto zachowań altruistycznych przyswojonych na drodze mechanizmu uległości wyrażony w ilości potomstwa; $b(c)$ - liczbę potomstwa wniesionego w skład populacji w wyniku zachowań altruistycznych A (wartość tę wyraża się za pomocą funkcji, ponieważ ilość altruizmu wymaganego od A - a w konsekwencji wkładu w przystosowanie innych — zależy od definicji zachowania właściwego, przyjmowanej w danym społeczeństwie); zaś $p$ - procentowy udział altruistów w populacji.
}

Ponieważ $F_{\mathrm{A}}-F_{\mathrm{S}}=d-c$, więc przystosowanie jednostek altruistycznych będzie wyższe niż samolubnych, o ile $d>c$. 
Idea ta polega na tym, że Matka Teresa albo Tomasz z Akwinu przejawiają „racjonalność ograniczoną". Nie są w stanie odróżnić zachowania zalecanego społecznie, które przyczynia się do ich przystosowania, od zachowania altruistycznego (zachowania społecznie zalecanego, które się doń nie przyczynia). W rezultacie nie są w stanie przyswoić wiedzy i umiejętności korzystnych dla siebie, które zapewniają wzrost $d$ przystosowania, nie doświadczywszy, niestety, zarazem spadku $c$, będącego konsekwencją zachowań altruistycznych. Bezmyślnie aprobują to, co z perspektywy społeczeństwa jest właściwym sposobem postępowania. Nie całkiem są w też stanie dokonać własnej, niezależnej oceny prawdopodobnego wpływu takiego zachowania na los ich genów. Gdyby dokonali takiej niezależnej oceny (oraz byli wystarczająco racjonalni, by uniknąć głupich błędów), przypuszczalnie zrozumieliby, że zachowanie tego rodzaju nie przyczynia się do ich własnego przystosowania, natychmiast by je zarzucili i wzięli się do roboty nad oczekiwaną liczbą potomstwa.

Żaden chrześcijanin nie mógłby zaakceptować tego ujęcia nawet jako punktu wyjścia możliwego wyjaśnienia altruistycznego zachowania osób w rodzaju Matki Teresy. Z chrześcijańskiej perspektywy nie można nawet powiedzieć, że mija się ono z rzeczywistością. Jest ono tak odległe od rzeczywistości, że nie można nawet mówić o mijaniu. Zachowywanie się jak Matka Teresa nie stanowi przejawu „racjonalności ograniczonej” — że mogłoby tak być, iż jeśli przemyślałaby tę kwestię jaśniej i wnikliwiej, to poniechałaby tego rodzaju zachowania i skupiła się na oczekiwanej liczbie własnego potomstwa. Jej zachowanie wyraża ducha Chrystusowego. Matka Teresa odzwierciedla na swój ograniczony, ludzki sposób wielką chwałę poświęcenia się Chrystusa w Dniu Pojednania. (Niewątpliwie jej zasługi zapisywane są także w niebie.) W rzeczy samej, czy cokolwiek, co może uczynić istota ludzka, jest bardziej racjonalne niż to, co robi Matka Teresa? W perspektywie chrześcijańskiej trudno traktować poważnie ideę, że jej zachowanie jest irracjonalne (i to tak irracjonalne, że wymaga wyjaśnienia w kategoriach mechanizmów, takich jak niezwykła uległość i racjonalność ograniczona!). W ujęciu Simona natomiast zachowanie tego typu, w jakie angażuje się Matka Teresa, stanowi wyłącznie przejaw „racjonalności ograniczonej”. Wręcz przeciwnie: jej zachowanie jest bez porównania bardziej racjonalne niż kogoś, kto, jak Cecil Jacobson, największy wysiłek poświęca dopilno- 
waniu, by jego geny były reprezentowane in excelsis w następnym i dalszych pokoleniach.

Czy jednak na pewno artykuł Simona można uznać za przykład nauki, która nie jest religijnie lub teologicznie neutralna? Simon sugeruje lub przyjmuje, że racjonalna droga postępowania jednostki ludzkiej (zawsze, często, czasami?) polega na próbie zwiększenia własnego przystosowania. Ale racjonalność jest pojęciem głęboko normatywnym. Racjonalna droga to droga właściwa, zalecana, którą powinno się podążać. Przeto Simon najwyraźniej wysuwa pewne normatywne twierdzenie lub, być może, przyjmuje pewne normatywne założenie. To twierdzenie czy założenie najwidoczniej stanowi kluczową i nieodłączną część jego propozycji. Jednakże jeśli tak, to czy rzeczywiście może ono stanowić część nauki? Jak mamy w tym wypadku rozumieć Simona? Nauka nie ma mieć charakteru oceniającego, normatywnego, preskryptywnego: ma dostarczać faktów, nie wartości. Czy twierdzenie, że racjonalna droga polega na dążeniu do przystosowania, może zatem być częścią jakiegoś obszaru nauki, naukowego wyjaśniania lub przedsięwzięć naukowych?

Prawdopodobnie da się znaleźć odpowiedź. Co według Simona dokładnie oznaczają takie terminy jak „racjonalny” i „racjonalność”? Przynajmniej dwie rzeczy: gdy mówi, że racjonalną — dla człowieka — drogą jest próba zwiększenia swojego przystosowania, to nie posługuje się tym terminem w taki sam sposób jak wówczas, gdy mówi, że Matka Teresa i podobni jej ludzie cierpią na przypadłość racjonalności ograniczonej. Ta ostatnia oznacza po prostu, że jeśli chodzi o cechy, takie jak inteligencja, bystrość i tym podobne, to ich poziom wśród takich ludzi nie jest całkowicie zadowalający. Pod względem bystrości umysłu ludzie ci są przynajmniej nieznacznie upośledzeni. To z powodu braku przenikliwości nie są $\mathrm{w}$ stanie dostrzec, że społecznie zalecane zachowania, o których mowa, naprawdę kolidują z ich własnym najlepszym interesem lub przeszkadzają w osiągnięciu ich własnych celów. Ta ograniczona racjonalność wynika $\mathrm{z}$ tego, że nie mają oleju w głowie, są naiwni lub brakuje im piątej klepki. Gdy jednak Simon mówi, że racjonalna droga postępowania dla człowieka polega na dążeniu do zwiększenia swojego przystosowania, prawdopodobnie używa terminu „racjonalny” w innym sensie. Jaki sens mógłby mieć on na myśli, aby jego projekt wciąż można było uznawać za naukowy? Być może taki: prawidłowo funkcjonująca, nieupośledzona istota ludzka (a więc taka, która nie 
jest szalona, niedorozwinięta, poddana nadmiernemu stresowi bądź dotknięta jakimś innym upośledzeniem lub stanem dysfunkcjonalnym) rzeczywiście ma pewne cele, stara się zrealizować pewne warunki lub doprowadzić do pewnych stanów rzeczy. Przypuszczalnie przetrwanie jest jednym z takich celów, lecz kolejny to, powiada Simon, zwiększenie lub maksymalizacja przystosowania.

$\mathrm{Na}$ temat tego twierdzenia należy powiedzieć dwie rzeczy. Po pierwsze, możemy zapytać, co przemawia za tym, że wszyscy lub prawie wszyscy ludzie funkcjonujący prawidłowo rzeczywiście przejawiają dążenie do tego celu? Niełatwo wyobrazić sobie, jak odpowiedzieć na to pytanie. Można podejrzewać, że badania przeprowadzone metodą zwykłego sondażu oraz technikami ankietowymi nie pomogłyby znaleźć odpowiedzi. W każdym razie większość prawidłowo funkcjonujących ludzi, których znam, nie uznałoby za jeden ze swoich głównych celów zwiększania własnego przystosowania. (Być może odpowiecie, iż jest tak dlatego, że większość znanych mi ludzi nie jest już w wieku reprodukcyjnym, zatem bezpośrednie zwiększanie reprezentacji ich genów w następnych pokoleniach nie jest już realną możliwością. Rzecz jasna, mogliby robić wszystko, co w ich mocy, aby mieć wielu wnuków — być może sprytnie rozdzielając łapówki albo aranżując odpowiednie okoliczności, aby ich córki zachodziły w ciążę, lub też zachęcając młodszych krewnych do rzucenia szkoły i płodzenia dzieci.) Oczywiście zawsze możemy wskazać inną możliwość: uznać, że wspomniane cele lub zamiary są nieuświadomione, znajdują się poza świadomą kontrolą. Determinuje je raczej zachowanie. To właśnie twoje zachowanie ujawnia i demonstruje twoje cele, niezależnie od tego, co o tym mówisz (i, w rzeczy samej, co o tym sądzisz).

Zgoda, możliwe, że tak jest. Nadal jednak należy dowieść lub uzasadnić, że zachowanie prawidłowo funkcjonujących osób naprawdę przejawia ów cel, czyli zwiększanie własnego przystosowania - naturalnie w tych wypadkach, kiedy nie możemy przyjąć, że przejawianie przez nich tego celu stanowi rzetelne kryterium normalności lub właściwego funkcjonowania. Należy zauważyć, że Simon nie postępuje w ten sposób. Procedura, jaką się posługuje w odniesieniu do tej kwestii, ma charakter aprioryczny, a nie aposterioryczny. Nie mówi nam, co skłoniło go do uznania, że prawidłowo funkcjonujące istoty ludzkie będą miały ten cel. Można podejrzewać, iż odpowiedziałby, że cel ten jest konsekwencją historii ewolucyjnej człowieka. Podejrzewam, że Simon sądzi, iż z każdego rzetel- 
nego ewolucyjnego wyjaśnienia genezy istot ludzkich (a także wielu innych gatunków) wynika, że ich celem jest maksymalizacja przystosowania. Być może nie jest zupełnie jasne, jak dokładnie miałoby do tego dojść, ale na razie możemy zignorować ten problem.

Po drugie, $w$ odniesieniu do analizowanego tu twierdzenia można zadać to samo pytanie, co wcześniej: czy sama idea prawidłowego funkcjonowania nie jest pojęciem normatywnym? Mamy tu do czynienia $\mathrm{z}$ kręgiem powiązanych pojęć: prawidłowe funkcjonowanie, zdrowie, normalność (w normatywnym, nie deskryptywnym sensie), dysfunkcja, uszkodzenie, projekt (prawidłowo funkcjonujące płuco pracuje w sposób, w jaki płuca zostały zaprojektowane do pełnienia swojej funkcji), cel i tym podobne. Być może żadnego $\mathrm{z}$ tych pojęć nie da się analizować za pomocą pojęć spoza tego zaklętego kręgu (zatem ów krąg stanowiłby odpowiednik takich powiązanych pojęć jak: konieczność, możliwość, wynikanie, światy możliwe i tak dalej). A czy pojęcia te nie mają charakteru normatywnego? W rzeczy samej, towarzyszy im użycie słowa „powinność”. Gdy zostanie wciśnięty rozrusznik, silnik powinien odpalić — czyli jeśli odpowiednie części funkcjonują prawidłowo, silnik odpali, gdy zostanie wciśnięty rozrusznik. Jeśli lekko się skaleczyłeś, wokół rany powinien utworzyć się strup, to znaczy jeśli odpowiednie części twojego ciała funkcjonują prawidłowo, to na ranie utworzy się strup. Sześciomiesięczne dziecko powinno być zdolne równocześnie unieść głowę i machać nóżkami, to znaczy zdrowe, normalne (w normatywnym, nie statystycznym sensie) sześciomiesięczne dziecko potrafi wykonywać te czynności. Czy nie musimy zatem uznać, że samo pojęcie prawidłowego funkcjonowania jest pojęciem normatywnym? Jeśli więc dla Simona „racjonalność" oznacza jedynie prawidłowe funkcjonowanie, to czy jego twierdzenia mają charakter normatywny, a tym samym nie wchodzą w zakres należycie pojmowanej nauki?

Być może, ale jeśli zastosowanie pojęcia normalności lub prawidłowego funkcjonowania wystarczy do pozbawienia danego dyskursu statusu nauki, to okaże się, że znacznie więcej koncepcji niż tylko Simonowskie wyjaśnienie altruizmu nie będzie już można uznać za naukowe. Rozważmy funkcjonalne generalizacje — rodzaj uogólnien, z jakimi mamy do czynienia w biologicznych i psychologicznych opisach funkcjonowania ludzi lub innych istot żywych. Jak 
wskazuje John Pollock, podstawą takich generalizacji jest pewne milczące założenie: gdy formułujemy podobne uogólnienia w odniesieniu do maszyn,

Formułowane przez nas generalizacje w rzeczywistości dotyczą sposobu działania maszyn, gdy „pracują prawidłowo” albo gdy „nie są zepsute”. Podobnie, generalizacje dotyczące organizmów powinno się rozumieć jako opisy sposobu działania organizmów, gdy „funkcjonują normalnie”. ${ }^{10}$

Zwroty „funkcjonujący normalnie” oraz ,niezepsuty” są tutaj bliskoznaczne z określeniami „niedotknięty żadnym zaburzeniem czynności”, „działający prawidłowo” albo „niefunkcjonujący wadliwie”. Zatem funkcjonalne generalizacje dotyczące organizmów mówią, jak one działają, gdy funkcjonują prawidłowo. Lecz oczywiście w naukach biologicznych i społecznych aż roi się od takich generalizacji. Przeto jeśli Simon w ramach swojego ujęcia racjonalności odwołuje się do pojęcia prawidłowego funkcjonowania, może odwoływać się do pewnego rodzaju normatywności. Ale ten rodzaj normatywności ma szerokie zastosowanie w nauce, a przynajmniej w ramach tego, co nazywamy nauką: niektórzy będą utrzymywać, że pojęcie prawidłowego funkcjonowania nie należy do nauki, chyba że da się je jakoś wyjaśnić w innych kategoriach — przypuszczalnie ostatecznie w kategoriach regularności, jakie bada fizyka i chemia. Nie musimy wkraczać na ten sporny teren. Wystarczy zauważyć, że jeśli Simon odwołuje się do pojęcia prawidłowego funkcjonowania, to w istocie odwołuje się do czegoś, co znajduje szerokie zastosowanie wzdłuż i wszerz nauk społecznych i biologicznych. Dlatego nie powinniśmy odmawiać miana „nauki” temu, co robi Simon, chyba że jesteśmy przygotowani, by skierować te same zarzuty w stronę znakomitej większości obszarów badawczych, które zaliczamy do nauk społecznych i biologicznych. A jeśli nawet uznamy, że Simonowska nauka w rzeczywistości nie jest nauką, zasadniczo niczego to nie zmieni. Opowiadam się nie za tym, że rozważania religijne wywierają wpływ na tak zwaną należycie pojmowaną naukę, lecz za tym, że wpływają na to, co naprawdę nazywane jest nauką i co rzeczywiście stanowi bardzo ważny, dominujący element naszego życia intelektualnego i kulturowego.

\footnotetext{
${ }^{10}$ John L. Pollock, „How to Build a Person: The Physical Basis for Mentality”, w: James E. Tomberlin (ed.), Philosophical Perspectives: Volume 1: Metaphysics, Ridgeview Publishing Company, Atascadero 1987, s. 148 [109-154].
} 
Przyjmę przeto, że Simonowska nauka jest nauką. To wyjaśnienie altruizmu stanowi przykład teorii naukowej, która ewidentnie nie jest neutralna w odniesieniu do chrześcijańskiego światopoglądu. W rzeczy samej, jest z nim niezgodna. Teoria Simona uwidacznia także jeszcze jeden, całkiem inny aspekt roli rozważań religijnych w nauce: rzutują one na nasze przekonania o tym, co wymaga wyjaśnienia. Z perspektywy Simona altruizm wymaga wyjaśnienia, natomiast z perspektywy chrześcijańskiej lub teistycznej oczekuje się jedynie, że ludzie czasem będą zachowywać się altruistycznie. Tym, co z tego drugiego punktu widzenia wymaga wyjaśnienia, jest raczej to, że ludzie są wobec siebie okrutni i wzajemnie się zabijają.

\section{Wielki Mit Ewolucji}

$\mathrm{Z}$ racji tego, że przykład ten przeanalizowałem gdzie indziej, w niniejszym artykule ograniczę się tylko do zwięzłego omówienia. ${ }^{11}$ Rozważmy Wielki Mit Ewolucji. Wedle tej opowieści życie organiczne powstało w jakiś sposób z nieożywionej materii drogą czynników czysto naturalnych, a także na mocy działania podstawowych regularności fizycznych i chemicznych. Gdy rozpoczęło się życie, całe nieprzebrane bogactwo współczesnej fauny i flory wyłoniło się z tych pierwszych przodków na zasadzie wspólnoty pochodzenia. Olbrzymia różnorodność współczesnego życia powstała zasadniczo drogą doboru naturalnego, oddziałującego na takie źródła zmienności genetycznej jak losowe mutacje genetyczne, dryf genetyczny i tym podobne. Nazywam tę opowieść mitem nie dlatego, że w nią nie wierzę (chociaż w nią nie wierzę), ale dlatego, że odgrywa ona pewnego rodzaju quasi-religijną rolę we współczesnej kulturze. Stanowi ona pewien wspólny sposób rozumienia nas samych na głębokim poziomie religii, głęboką interpretację nas samych dla nas samych, wzorzec odpowiedzi na pytania: dlaczego tutaj jesteśmy, skąd pochodzimy i dokąd zmierzamy. ${ }^{12}$

Naturalnie jest możliwe - w każdym razie możliwe pod względem epistemicznym - że Wielki Mit Ewolucji jest prawdziwy. Z pewnością Bóg mógł po-

\footnotetext{
${ }^{11}$ Por. przyp. 4.

${ }^{12}$ Pominę tu nauki pierwszej części Księgi Rodzaju, ponieważ nie jestem pewny, jaki dokładnie wywierają wpływ na omawianą kwestię (por. Plantinga, „Evolution, Neutrality...”, s. 94).
} 
służyć się ewolucją. Trzeba jednak stwierdzić, że pewne fragmenty tej opowieści są wątpliwe, przynajmniej z perspektywy epistemicznej. Na przykład prawie w ogóle nie dysponujemy przekonującymi wskazówkami, jak dzięki działaniu prawidłowości znanych fizyce i chemii z materii nieorganicznej mogło powstać życie. ${ }^{13}$ (Darwin uznawał tę kwestię za bardzo kłopotliwą. ${ }^{14}$ Współcześnie problem ten jest znacznie trudniejszy niż w czasach Darwina, gdyż całkiem dobrze poznaliśmy już zdumiewającą złożoność nawet najprostszych form życia. ${ }^{15}$ ) Bez wątpienia Bóg mógłby zaaranżować bieg wydarzeń w ten sposób, gdyby taki był jego wybór, lecz obecnie wygląda na to, że nie wybrał tej drogi.

Przyjmijmy zatem, że odcinamy się od tej tezy o pochodzeniu życia. Przyjmijmy, że używamy terminu „ewolucja” na oznaczenie znacznie słabszego twierdzenia - iż wszystkie współczesne formy życia są genealogicznie spokrewnione. Zgodnie $\mathrm{z}$ tym twierdzeniem ty i kwiaty w twoim ogrodzie macie wspólnych przodków, chociaż znalezienie ich może wymagać cofnięcia się daleko w czasie. Wielu współczesnych ekspertów i rzeczników tej tezy - przykładowo Francisco J. Ayala, Richard Dawkins, Stephen J. Gould, William Pro-

\footnotetext{
${ }^{13}$ W roku 1952 Stanley Miller, doktorant w laboratorium Harolda Ureya, wykazał, że pewne aminokwasy mogą powstać w warunkach, jakie przypuszczalnie panowały na Ziemi przed powstaniem życia. Płomienny i dytyrambiczny optymizm towarzyszący przez krótki czas temu odkryciu został ugaszony, gdy zdano sobie sprawę z olbrzymiego dystansu dzielącego aminokwasy i najprostsze formy życia, a następnie gdy okazało się, że próby wykazania, iż ten dystans mógłby zostać pokonany, przynoszą niewielkie rezultaty lub zgoła żadnych (por. zwł. Robert SHAPIRo, Origins: A Skeptic's Guide to the Creation of Life on Earth, Summit Books, New York 1986 oraz Charles B. Thaxton, Walter L. Bradley, and Roger L. Olsen, The Mystery of Life's Origin: Reassesing Current Theories, Philosophical Library, New York 1984).

${ }^{14}$ „Roztrząsanie w tym momencie problemu powstania życia byłoby niedorzecznością; równie dobrze można by zastanawiać się nad powstaniem materii” (list Karola Darwina do Josepha Daltona Hookera z dnia 29 marca 1863 roku w: Francis Darwin (ed.), The Life and Letters of Charles Darwin, vol. 2, Appleton, New York 1967, s. 202).

${ }^{15}$ Por. Thaxton, Bradley, and Olsen, The Mystery of Life's Origin...; Shapiro, Origins...; Jeffrey. S. WiCKEn, Evolution, Thermodynamics, and Information: Extending the Darwinian Program, Oxford University Press, New York 1987; Alexander Graham CaIrns-Smith, Seven Clues to the Origin of Life: A Scientific Detective Story, Cambridge University Press, Cambridge 1985; Alexander Graham Cairns-Sмiтh, Genetic Takeover and the Mineral Origins of Life, Cambridge University Press, Cambridge 1985; Freeman J. Dyson, Początki życia, przeł. Paweł Golik, Biblioteka Myśli Wspótczesnej, Państwowy Instytut Wydawniczy, Warszawa 1993; por. też odpowiednie rozdziały w: Michael Denton, Evolution: A Theory in Crisis, Burnet Books, London 1985.
} 
vine i Philip Spieth — jednomyślnie deklaruje, że ewolucja nie jest tylko teorią, lecz ustalonym faktem. Według nich opowieść tę cechuje nie po prostu pewność wirtualna, lecz pewność realna. ${ }^{16}$ Dlaczego tak sądzą? Biorąc pod uwagę niekompletny charakter danych empirycznych - na przykład widoczne w zapisie kopalnym nagłe pojawianie się nowych form życia i następującą po nim stazę oraz nieliczne, o ile jakiekolwiek, autentyczne przykłady makroewolucji, jak również brak satysfakcjonującego wyjaśnienia mechanizmu, który mógłby kierować całym tym procesem, i tym podobne ${ }^{17}$ - te pełne pewności twierdzenia w najlepszym razie wydają się mocno przesadzone. Sądzę, że zrozumiemy, skąd się bierze ta pewność ewolucjonistów, gdy zdamy sobie sprawę, że to przeświadczenie o mocy ich twierdzeń częściowo zależy od stosunku do teizmu. Jeśli odrzucamy teizm na rzecz naturalizmu, to ta ewolucyjna opowieść staje się jedynym możliwym wyborem, jedyną realną odpowiedzią na pytania: „Skąd się wzięła cała ta olbrzymia różnorodność fauny i flory? Jak się tutaj znalazła?” Nawet jeśli zapis kopalny jest $\mathrm{w}$ najlepszym razie nieciągły, w najgorszym zaś przemawia przeciwko teorii ewolucji, to i tak opowieść ewolucyjna pozostaje je-

\footnotetext{
${ }^{16}$ Ewolucja, powiada Francisco J. Ayala, jest tak równie pewna jak „kulistość Ziemi, ruchy planet i cząsteczkowa budowa materii” (Francisco J. Ayala, „Theory of Evolution: Recent Successes and Challenges", w: Ernan McMuluin (ed.), Evolution and Creation, University of Notre Dame Press, Notre Dame 1985, s. 60 [59-90]). Według Stephena J. Goulda ewolucja jest ustalonym faktem, a nie zwykłą teorią. A przeto nikt rozsądny, kto zapoznał się z danymi empirycznymi, nie może się jej sprzeciwiać (por. Stephen J. Gould, „Ewolucja jako fakt i teoria”, w: Stephen J. Gould, Niewczesny pogrzeb Darwina. Wybór esejów, wyd. 2., przeł. Nina Kancewicz-Hoffman, Prószyński i S-ka, Warszawa 1999, s. 132-134 [131-142]). Zdaniem Richarda Dawkinsa teoria ewolucji jest tak samo pewna jak to, że Ziemia krąży wokół Słońca (por. Richard Dawkins, Samolubny gen, przeł. Marek Skoneczny, Na Ścieżach Nauki, Prószyński i S-ka, Warszawa 1996, s. 18 - przyp. thum.). To porównanie do astronomii wielu ludziom najwyraźniej nasuwa się samo. Philip Spieth twierdzi, że „125 lat po opublikowaniu O powstawaniu gatunków biolodzy mogą stwierdzić $\mathrm{z}$ całą pewnością, że uniwersalne pokrewieństwo genealogiczne to wniosek wypływający $\mathrm{z}$ badań prowadzonych $\mathrm{w}$ ramach nauk przyrodniczych, który jest dowiedziony równie mocno, jak obrót Ziemi wokół Słońca” (Philip T. SPIETH, „Evolutionary Biology and the Study of Human Nature", nieopublikowany artykuł, zaprezentowany na konferencji dotyczącej kosmologii i teologii, sponsorowanej przez Kościół Prezbiteriański w Stanach Zjednoczonych w grudniu 1987 roku). Zaś Michael Ruse dokłada swój pełen niuansów, modulowany pogląd, że „ewolucja jest Faktem, Faktem, Faktem!” (Michael Ruse, Darwinism Defended: A Guide to Evolution Controversies, Addison-Wesley, Reading, Massachusetts 1982, s. 58).

${ }^{17}$ Por. eseje, do których odsyła przyp. 4.
} 
dyną (z perspektywy naturalistycznej) odpowiedzią, jakiej można udzielić na te pytania.

W perspektywie chrześcijańskiej sytuacja jest jednak znacznie mniej rozpaczliwa. Teista wie, że to Bóg stworzył niebo i ziemię wraz ze wszystkim, co się w nich znajduje. Wie przeto, że Bóg w ten czy inny sposób stworzył całą nieprzebraną różnorodność współczesnego życia roślinnego i zwierzęcego. Oczywiście teista nie jest wskutek tego zobowiązany do opowiedzenia się za jakimkolwiek konkretnym sposobem, w jaki Bóg tego dokonał. W zasadzie Bóg mógł posłużyć się ewolucją, ale z drugiej strony mógł to sprawić w jakiś zupełnie inny sposób. Przykładowo mógł to uczynić drogą bezpośredniego stworzenia pewnych rodzajów istot - ludzi, bakterii, a także wróbli ${ }^{18}$ czy much domowych - jak przez stulecia sądziło wielu chrześcijan. Ewentualnie Bóg mógł stwarzać w sposób, jaki sugeruje Augustyn: poprzez zasianie w świecie nasion, różnorodnych potencjalności w taki sposób, że później powstały rozmaite rodzaje istot, jednak nie na drodze wzajemnego pokrewieństwa genealogicznego. Obie te sugestie są niezgodne $\mathrm{z}$ ewolucyjną opowieścią.

Chrześcijanin cieszy się więc pewną wolnością, która nie przysługuje jego naturalistycznemu odpowiednikowi: może podążać za świadectwami ${ }^{19}$ tam, dokąd prowadzą. Jeśli wyraźnie sugerują one, że Bóg dokonał czegoś wyjątkowego, stwarzając ludzi (w taki sposób, że nie są genealogicznie spokrewnieni $\mathrm{z}$ resztą stworzenia) ${ }^{20}$ albo gady czy cokolwiek innego, to nic nie zabrania mu wierzyć, że Bóg sprawił właśnie to. Prawdopodobnie sedno omawianej sprawy można wyrazić następująco: w zależności od przyjętej perspektywy — teistycznej bądź naturalistycznej - epistemiczne prawdopodobieństwo całości wielkiej ewolucyjnej opowieści jest zupełnie inne. Prawdopodobieństwo wyjaśnienia ewolucyjnego $\mathrm{w}$ odniesieniu do świadectw empirycznych oraz poglądów, jakie zazwyczaj utrzymuje teista, jest znacznie niższe od prawdopodobieństwa tego

\footnotetext{
${ }^{18}$ Wedle słów Jezusa Bóg pamięta o wszystkich wróblach razem i o każdym z osobna (Łk 12:6). Czyż nie mógłby stworzyć pierwszego wróbla na drodze specjalnego stworzenia?

${ }^{19}$ A dla chrześcijan naturalnie część świadectw będzie świadectwami biblijnymi. Ja sam sądzę, że biblijne świadectwo na rzecz specjalnego stworzenia istot ludzkich jest bardzo silne.

${ }^{20}$ Oczywiście możliwe jest zarówno, że Bóg, stwarzając ludzi, dokonał czegoś wyjątkowego, jak i to, że jesteśmy genealogicznie spokrewnieni z resztą świata ożywionego.
} 
wyjaśnienia w odniesieniu do świadectw empirycznych oraz poglądów utrzymywanych zazwyczaj przez naturalistę. Zatem teoria ewolucji nie jest religijnie neutralna dlatego, że - jak w przypadku Simonowskiego wyjaśnienia postępowania Matki Teresy - po prostu nie da się jej pogodzić z tym, czego naucza chrześcijaństwo. Rzecz sprowadza się raczej do tego, że teoria ewolucji jest znacznie bardziej prawdopodobna w odniesieniu do naturalizmu oraz świadectw empirycznych niż w odniesieniu do teizmu oraz tychże świadectw.

$\mathrm{W}$ ramach tej dziedziny jest jeszcze jedna, pokrewna kwestia, aczkolwiek akcent pada tu gdzie indziej. Czołowi przedstawiciele społeczności naukowej na przykład Dawkins, Futuyma, Gould, Provine, Simpson i inni — jednogłośnie deklarują, że biologia ewolucyjna wykazuje, iż zasadniczą rolę w powstaniu i rozwoju gatunku ludzkiego odgrywa czynnik losowości czy przypadkowości. Dlatego (jak twierdzą) ludzie nie zostali zaprojektowani przez Boga ani nikogo innego. Gould pisze: „przed Darwinem sądziliśmy, że stworzył nas łaskawy Bóg". " Po Darwinie zaś, twierdzi Gould, pojęliśmy, iż:

Żaden interweniujący duch nie troszczy się o to, co dzieje się w przyrodzie (chociaż nakręcający zegar Newtonowski Bóg mógł na początku czasu nastawić ten mechanizm, a potem pozostawić go swemu własnemu biegowi). Żadne siły witalne nie napędzają zmian ewolucyjnych. Cokolwiek sądzimy o Bogu, jego istnienie nie przejawia się w wytworach przyrody. ${ }^{21}$

Futuyma jaśniej wyraża zapatrywania Goulda:

Poprzez sprzężenie niekierowanej, pozbawionej celu zmienności i ślepego, obojętnego procesu doboru naturalnego Darwin sprawił, że teologiczne czy duchowe wyjaśnienia stały się zbyteczne. Wraz z Marksowską materialistyczną teorią historii i społeczeństwa oraz Freudowskim przypisaniem ludzkiego zachowania procesom, nad którymi

\footnotetext{
* (Przyp. thum.) Stephen J. Gould, „So Cleverly Kind of an Animal”, w: Stephen J. Gould, Ever Since Darwin: Reflections in Natural History, W.W. Norton \& Company, New York London 1977, s. 267 [260-267]. Wcześniej artykuł ten ukazał się w czasopiśmie Natural History 1976, vol. 86, no. 9, s. 32-36.

${ }^{21}$ Stephen J. Gould, „In Praise of Charles Darwin”, w: Charles L. Hamrum (ed.), Darwin's Legacy: Nobel Conference XVIII, Harper \& Row, San Francisco 1983, s. 6-7.

(Przyp. tłum.) Najpierw artykuł ten ukazał się w czasopiśmie Discover 1982, vol. 3, no. 2, s. $20-25$.
} 
mamy niewielką kontrolę, Darwinowska teoria ewolucji stała się zasadniczym elementem programu mechanicyzmu oraz materializmu — krótko mówiąc: znacznej części nauki — i stanowiła odtąd scenerię dla przeważającej części myśli Zachodu. ${ }^{22}$

Być może jeszcze jaśniej wyraża się George Gaylord Simpson:

Chociaż do opracowania pozostaje wiele szczegółów, jest już oczywiste, że wszystkie obiektywne zjawiska w historii życia da się wyjaśnić, odwołując się do czynników czysto naturalistycznych lub - we właściwym sensie tego czasami nadużywanego słowa - materialistycznych. Szczegóły te łatwo da się wyjaśnić na podstawie różnicowej reprodukcji w obrębie populacji (głównego czynnika we współczesnej koncepcji doboru naturalnego) oraz przeważnie losowego wzajemnego oddziaływania znanych mechanizmów dziedziczności. [...] Człowiek stanowi rezultat pozbawionego celu procesu naturalnego, który nie miał go na uwadze. ${ }^{23}$

To samo twierdzenie wysunął Richard Dawkins:

Wbrew wszelkim pozorom jedynym zegarmistrzem w przyrodzie są ślepe siły fizyczne — choć działają w pewien bardzo szczególny sposób. Prawdziwy zegarmistrz przewiduje. Projektuje swoje kółka zębate i sprężyny, planuje połączenia między nimi odpowiednio do ich przyszłego zastosowania, jakie widzi w swej wyobraźni. Natomiast dobór naturalny — odkryty przez Darwina ślepy, bezrozumny i automatyczny proces, o którym wiemy dziś, że stanowi wyjaśnienie zarówno istnienia, jak i pozornej celowości wszystkich form życia — działa bez żadnego zamysłu. Nie ma ani rozumu, ani wyobraźni. Nic nie planuje na przyszłość. Nie tworzy wizji, nie przewiduje, nie widzi. Jeśli w ogóle można o nim powiedzieć, że odgrywa w przyrodzie rolę zegarmistrza to jest to ślepy zegarmistrz. ${ }^{24}$

Autorzy cytowani powyżej jednomyślnie deklarują, iż współczesna myśl ewolucyjna wykazała lub przynajmniej dała powody, by sądzić, że ludzie powstali w istocie przez zwykły przypadek. Zaistnieniu człowieka nie towarzyszył

\footnotetext{
${ }^{22}$ Douglas J. Futuyma, Evolutionary Biology, 2nd ed., Sinauer Associates, Sunderland 1986, s. 3.

${ }^{23}$ George Gaylord Simpson, The Meaning of Evolution: A Study of the History of Life and its Significance for Man, rev. ed., Yale University Press, New Haven 1967, s. 344-345.

${ }^{24}$ Richard DAwKINS, Ślepy zegarmistrz, czyli jak ewolucja dowodzi, że świat nie został zaplanowany, przeł. Antoni Hoffman, Biblioteka Myśli Wspótczesnej, Państwowy Instytut Wydawniczy, Warszawa 1994, s. 27 (w polskim przekładzie słowo „ślepy” nie jest wyróżnione — przyp. thum.).
} 
żaden plan, żadne przewidywanie, żadne wyobrażenie czy zamysł. Ale oczywiście żaden teista chrześcijański ani przez chwilę nie potraktowałby tego poważnie. Istoty ludzkie zostały stworzone i to na obraz i podobieństwo Boże. Bez wątpienia Bóg mógł nas stworzyć drogą procesów ewolucyjnych. Lecz jeśli tak postąpił, to musiał przewodzić i nadawać kierunek procesom, którymi posłużył się w realizacji swoich zamiarów.

Możemy ponownie (jak w przypadku Simona) stwierdzić, że ściśle rzecz biorąc, gdy przywoływani autorzy składają takie deklaracje, to ani nie wypowiadają się jako naukowcy, ani nie uprawiają nauki. Za to komentują naukę, wyciągają wnioski z odkryć naukowych — wnioski, które nie wynikają z samych tych odkryć, lecz wymagają dodatkowych, pozanaukowych (przypuszczalnie filozoficznych) przesłanek. Możliwe, że to prawda, chociaż nakreślenie ostrej granicy pomiędzy nauką a innymi formami ludzkiej działalności, takimi jak filozoficzna refleksja nad nauką, staje się coraz trudniejsze. Jednak niezależnie od tego, czy jest to nauka czy paranauka, jesteśmy głęboko zaangażowani w duchowy konflikt, na który wskazywał Augustyn. W obu przypadkach chrześcijańska społeczność intelektualna musi zauważyć ten problem i się z nim zmierzyć. W szczególności dotyczy to chrześcijańskich naukowców pracujących w dziedzinach, w których toczy się omawiany spór.

\section{Kosmiczne subtelne zestrojenie}

Trzeci przykład, który przytoczę, dotyczy „subtelnego zestrojenia” w kosmologii. Począwszy od przełomu lat sześćdziesiątych i siedemdziesiątych dwudziestego wieku astrofizycy i inni uczeni zauważyli, że aby mógł nastąpić rozwój inteligentnego życia - przynajmniej drogą jakkolwiek podobną do tej, którą według nas faktycznie przebiegał - wartości kilku fundamentalnych stałych fizycznych muszą mieścić się w bardzo wąskim zakresie. Jak zauważyli Carr i Rees:

Podstawowe cechy galaktyk, gwiazd, planet i świata codziennego są zasadniczo zdeterminowane przez kilka stałych mikrofizycznych oraz przez efekty grawitacyjne. [...] kilka aspektów naszego Wszechświata — niektóre $\mathrm{z}$ nich wydają się niezbędne dla 
ewolucji wszystkich form życia — w dość subtelny sposób zależy od widocznych „koincydencji” pomiędzy stałymi fizycznymi. ${ }^{25}$

Przykładowo, gdyby siła grawitacji była tylko nieznacznie większa, to wszystkie gwiazdy stałyby się błękitnymi olbrzymami, jeśli zaś nieznacznie mniejsza, to wszystkie byłyby czerwonymi karłami. W obu przypadkach nie mogłoby powstać życie. ${ }^{26}$ To samo zachodzi w przypadku słabych i silnych oddziaływań jądrowych. Jeśli wartość któregokolwiek z nich różniłaby się tylko nieznacznie, to życie, w każdym razie takie, jakie znamy, prawdopodobnie nie mogłoby się rozwinąć.

Jeszcze bardziej interesujący jest tak zwany problem płaskości: najwidoczniej istnienie życia także w bardzo subtelny sposób uzależnione jest od tempa ekspansji Wszechświata. Według Stephena Hawkinga:

[...] zmniejszenie tempa ekspansji Wszechświata rzędu $10^{-12} \mathrm{w}$ momencie, gdy temperatura Wszechświata wynosiła $10^{10} \mathrm{~K}$, spowodowałoby, że Wszechświat uległby kolapsowi, gdy jego promień wynosiłby tylko 1/3000 wartości obecnej, a jego temperatura - nadal $10000 \mathrm{~K} .{ }^{27}$

Byłoby więc o wiele za gorąco, by zapewnić dogodne warunki. Hawking doszedł do wniosku, że życie jest możliwe wyłącznie dlatego, że Wszechświat rozszerza się dokładnie w takim tempie, które uniemożliwia kolaps. Na wcze-

${ }^{25}$ Bernard J. CARr and Martin J. Rees, „The Anthropic Principle and the Structure of the Physical World", Nature 1979, vol. 278, s. 605 [605-612].

${ }^{26}$ Por. Brandon CARTER, „Large Number Coincidences and the Anthropic Principle in Cosmology”, w: Malcolm S. Longair (ed.), Confrontation of Cosmological Theories with Observational Data, Reidel Publishing Company, Dodrecht — Boston 1974, s. 297 [291-298]. Carter doszedł do wniosku, że gdyby siła grawitacji tylko nieznacznie różniła się od obecnej, nie byłoby planet nadających się do zamieszkania.

${ }^{27}$ Stephen W. Hawking, „The Anisotropy of the Universe at Large Times”, w: Longair (ed.), Confrontation of Cosmological Theories..., s. 285 [283-286].

(Przyp. tłum.) Przekład polski większej części (okrojonej o argumentację matematyczną) tego artykułu ukazał się jako: Stephen W. HAwKING, „Wszechświat a człowiek”, przeł. Bolesław Rok, w: Michał Hempoliński (red.), Ontologia. Antologia tekstów filozoficznych, Ossolineum, Wrocław - Warszawa - Kraków 1994, s. 399-401. 
śniejszych etapach ekspansji Wszechświata subtelne zestrojenie musiało być jeszcze bardziej niezwykłe:

Wiemy na przykład, że musiała zaistnieć bardzo ścisła równowaga między konkurującymi z sobą skutkami ekspansji po wybuchu oraz grawitacyjnym ścieśnieniem, któremu - w najwcześniejszym okresie, o którym możemy w ogóle próbować mówić (zwanym okresem Plancka, $10^{-43}$ sekundy po Wielkim Wybuchu) — odpowiadała niewyobrażalna dokładność rozkładu gęstości, wyrażona niezwykle drobnym odchyleniem od nierozróżnialnej jedności, rzędu $10^{-60} .{ }^{28}$

Fakty te robią duże wrażenie. Należy zgodzić się z Paulem Daviesem: „fakt, że zachodzenie tych związków jest konieczne dla naszego istnienia, stanowi jedno z najbardziej fascynujących odkryć współczesnej nauki". ${ }^{29}$

$\mathrm{Z}$ jednej strony te wyraźne, wielkie koincydencje można postrzegać jako potwierdzenie teistycznego twierdzenia, że Wszechświat został stworzony przez osobowego Boga, oraz jako przesłankę dobrze wyważonego argumentu na rzecz teizmu. ${ }^{30} \mathrm{Z}$ drugiej strony można twierdzić, że żadna $\mathrm{z}$ tych koincydencji nie musi domagać się wyjaśnienia: niezależnie przecież od tego, jakby się rzeczy

${ }^{28}$ John C. Polkinghorne, Nauka i Stworzenie. Poszukiwanie zrozumienia, przeł. Marek Chojnacki, Wiara i Nauka, Wydawnictwo WAM, Kraków 2008, s. 55.

(Przyp. tłum.) Końcowy fragment ostatniego zdania należałoby przełożyć następująco: „odpowiadała niezwykła jednorodność rozkładu gęstości wyrażona niezwykle małym odchyleniem od ich stosunku 1:1 o jedną na $10^{60}$ części”.

${ }^{29}$ Paul DAvies, The Accidental Universe, Cambridge University Press, Cambridge 1991, s. 130. Davies dodaje:

Wszystko to nasuwa pytanie, dlaczego z nieskończonego przedziału możliwych wartości, które przyroda mogła wybrać dla stałych fundamentalnych, oraz z nieskończonej różnorodności warunków początkowych, które mogły charakteryzować pierwotny Wszechświat, właśnie te wartości i warunki zmówiły się, aby wytworzyć konkretny przedział bardzo szczególnych własności, jakie obserwujemy? Wyraźnie widać bowiem, że Wszechświat jest bardzo szczególnym miejscem: jest nadzwyczaj jednorodny w dużej skali, chociaż nie tak doskonale jednorodny, żeby nie mogły ukształtować się galaktyki; [...] tempo ekspansji zostało zestrojone z zawartością energii z niewiarygodną precyzją; wartości natężenia sił są takie, że mogą istnieć jądra atomowe, chociaż nie powodują wypalenia się całego wodoru w Kosmosie, a takich dostrzegalnych zbiegów okoliczności jest znacznie więcej (DAvIEs, The Accidental Universe..., s. 111).

${ }^{30}$ Por. np. Polkinghorne, Nauka i Stworzenie..., s. 57. 
miały, byłoby niezmiernie nieprawdopodobne, że jest właśnie tak, a nie inaczej. Twierdzenie to, we właściwym rozumieniu, jest prawdopodobnie słuszne, lecz na ile jest ono przekonujące? Gramy w pokera. Za każdym razem, gdy rozdaję, dostaję cztery asy i dziką kartę. Stajesz się podejrzliwy. Rozwiewam twoje wątpliwości wskazując, iż przy danej liczbie rozdań to, że za każdym razem, gdy rozdaję, mam akurat te karty, jest tak samo prawdopodobne jak otrzymanie każdego innego równie specyficznego rozkładu kart. ${ }^{31} \mathrm{Czy}$ to wyjaśnienie brzmiałoby przekonująco w Dodge City albo Tombstone? *

Jeszcze innym rozwiązaniem jest odwołanie się do Zasady Antropicznej, która występuje w kilku odmianach i nadzwyczaj trudno ją zrozumieć. ${ }^{32}$ Zasada ta (w najsensowniejszej wersji) zdaje się wskazywać, że warunkiem koniecznym zaistnienia jakiegokolwiek obserwatora tych wartości stałych kosmologicznych jest to, żeby te stałe miały wartości bardzo zbliżone do tych, jakie te stałe faktycznie mają. Jesteśmy tu i możemy obserwować te stałe wyłącznie dlatego, że mają dokładnie takie wartości, jakie mają. Powtórzmy, że twierdzenie to wydaje się słuszne, ale co ono wyjaśnia? Nadal pozostaje zagadką, dlaczego warto-

\footnotetext{
${ }^{31}$ Nietrudno zrozumieć, dlaczego w tym wypadku gra w pokera prawdopodobnie skończyłaby się strzelaniną. Prawdopodobieństwo uzyskania takiego rozkładu jest znacznie większe przy hipotezie, że oszukuję, niż przy hipotezie, że karty zostały rozdane uczciwie. Z twierdzenia Bayesa wynika zatem, że prawdopodobieństwo, że ten konkretny rozkład jest rezultatem oszustwa, jest znacznie większe niż przy innych rozkładach. To samo odnosi się do argumentów na rzecz subtelnego zestrojenia: prawdopodobieństwo subtelnego zestrojenia przy hipotezie, że Bóg stworzył Wszechświat, jest znacznie większe niż przy hipotezie, iż Wszechświat nie został stworzony. Stąd prawdopodobieństwo tego, że Bóg stworzył Wszechświat, jest większe przy założeniu subtelnego zestrojenia niż przy innych rozkładach wartości fundamentalnych stałych kosmologicznych.

* (Przyp. thum.) Miasta te zdobyły miano miast bezprawia na Dzikim Zachodzie, gdyż ich bogactwo przyciągało nie tylko kowbojów i górników, lecz także rewolwerowców i różnorakich oszustów. Na tym tle często dochodziło do burd i strzelanin, rzadziej — pojedynków. W Dodge City powstał nawet specjalny cmentarz dla ofiar zabójstw i pojedynków. W Tombstone 26 października 1886 miała miejsce strzelanina w O.K. Corral — jeden z najsłynniejszych epizodów w historii Dzikiego Zachodu (por. Jarosław Racięski i Edward KabIESz (red.), Encyklopedia Dzikiego Zachodu, Videograf II, Katowice 1996, s. 43, 46-47, 122).

${ }^{32}$ Martin Gardner rozróżnia Słabą Zasadę Antropiczną (SZA), Mocną Zasadę Antropiczną (MZA), Finalną Zasadę Antropiczną (FZA), Partycypacyjną Zasadę Antropiczną (PZA) oraz Zupełnie Niedorzeczną Zasadę Antropiczną (ZNZA) (akronim tworzący angielskie słowo CRAP przyp. thum.). Por. jego artykuł „WAP, SAP, PAP and FAP”, New York Review of Books 8 May 1987 , no. 33 , s. $22-25$.
} 
ści tych stałych powinny być właśnie takie, jakie są. Dlaczego nie miałyby być zupełnie inne? Nie można tego wyjaśnić wskazując, że rzeczywiście jesteśmy tutaj — nie bardziej niż mogę „wyjaśnić” fakt, że Bóg zdecydował się mnie stworzyć (zamiast pominąć mnie na rzecz kogoś innego), wskazując, że jeśliby Bóg tak nie zdecydował, nie byłoby mnie tutaj, abym mógł zadać to pytanie.

Jednak najbardziej interesujące mnie tu rozwiązanie jest inne i robi ono duże wrażenie:

Modele homogeniczne przestrzennie można podzielić na trzy klasy: te, których prędkość jest mniejsza od prędkości ucieczki (to jest takie, których tempo ekspansji jest niewystarczające, by zapobiec ich kolapsowi); te, których prędkość jest równa prędkości ucieczki, oraz te, których prędkość jest większa od prędkości ucieczki. Modele należące do pierwszej klasy istnieją tylko w skończonym czasie i dlatego nie zmierzają dowolnie blisko do izotropowości. Wykazaliśmy, że modele należące do trzeciej klasy na ogół zmierzają do izotropowości w dowolnie długim czasie. Te spośród modeli należących do drugiej klasy, które znajdują się dostatecznie blisko modeli RobertsonaWalkera, zwykle zmierzają do izotropowości, ale ta klasa charakteryzuje się zerową miarą w zakresie wszystkich modeli homogenicznych. $Z$ tego powodu prawdopodobnie nie można wyjaśnić izotropowości Wszechświata bez postulowania szczególnych warunków początkowych. [...]

Sądzimy, że najatrakcyjniejsza odpowiedź jest konsekwencją idei Dickiego-Cartera, że istnieje bardzo duża liczba wszechświatów, w których realizują się wszystkie możliwe kombinacje danych początkowych i wartości stałych fundamentalnych. We wszechświatach, których prędkość jest mniejsza od prędkości ucieczki, nie będzie czasu na to, aby niewielkie perturbacje gęstości przerodziły się w galaktyki i gwiazdy, zanim wszechświat ulegnie kolapsowi. We wszechświatach, których prędkość jest większa od prędkości ucieczki, niewielkie perturbacje gęstości nadal będą mieć prędkość większą od prędkości ucieczki, a więc nie utworzą się systemy grawitacyjnie związane. Można oczekiwać, że galaktyki rozwiną się wyłącznie we wszechświatach, których prędkość jest bardzo zbliżona do prędkości ucieczki, i odkryliśmy, że takie wszechświaty w zasadzie będą zmierzać do izotropowości. Ponieważ wiele wskazuje, że istnienie galaktyk stanowi warunek konieczny powstania inteligentnego życia, odpowiedź na pytanie „dlaczego Wszechświat jest izotropowy?” brzmi: „ponieważ tu jesteśmy". ${ }^{33}$

\footnotetext{
${ }^{33}$ C.B. Collins and Stephen W. Hawking, ,Why is the Universe Isotropic?”, The Astrophysical Journal 1973, vol. 180, no. 2, s. 333-334 [317-334].
} 
Idea wyrażona powyżej jest jasna: takie wartości stałych kosmologicznych oraz tempo ekspansji Wszechświata w naszym Wszechświecie rzeczywiście są zagadkowe i należy je wyjaśnić. Wyjaśnienie polega po prostu na tym, że istnieje nieskończenie wiele wszechświatów, w których realizują się wszystkie możliwe kombinacje warunków początkowych i wartości stałych fundamentalnych. Dlatego nie jest niczym zaskakującym, że powinniśmy zajmować jeden z wszechświatów, w których wartości te pozwalają na rozwój inteligentnego życia. ${ }^{34}$ Są to echa Davida Lewisa i postulowanych przezeń alef $f_{2}$ konkretnych światów możliwych! ${ }^{35}$ Sądzę, że zgodnie z hipotezą Hawkinga musiałaby istnieć przynajmniej niezliczona ilość takich wszechświatów, ponieważ przypuszczalnie istnieje pewien rzeczywisty interwał bliski 1, taki że dla każdej liczby rzeczywistej $r \mathrm{w}$ tym interwale stosunek efektu gwałtownej ekspansji do kontrakcji grawitacyjnej wynosiłby $r$.

W zasadzie mógłbym na tym poprzestać, ale żeby być au courant i na czasie, wspomnę o paru kwestiach wynikłych w dalszym rozwoju tej toczącej się nadal, fascynującej historii. ${ }^{36} \mathrm{~W} 1980$ roku Alan Guth zasugerował rozwiązanie

\footnotetext{
${ }^{34} \mathrm{~W}$ ostatnim zdaniu cytowanego artykułu można dostrzec pewne nieporozumienie, jakie towarzyszy zasadzie antropicznej. Zdanie ,ponieważ tu jesteśmy” nie jest odpowiedzią na pytanie: „dlaczego Wszechświat jest izotropowy?”, aczkolwiek zdanie: „wyłącznie dlatego, że Wszechświat jest izotropowy” może być odpowiedzią na pytanie: „dlaczego jesteśmy tutaj?” Sugestii tej towarzyszą także inne problemy: por. John EArman, „The SAP Also Rises: A Critical Examination of the Anthropic Principle”, American Philosophical Quarterly 1987, vol. 24, no. 4, s. 314315 [307-317].

${ }^{35}$ Por. David K. Lewis, On the Plurality of Worlds, Basil Blackwell Limited, Oxford 1986.

(Przyp. tłum.) W polskim przekładzie ukazał się artykuł Lewisa oparty na materiale z książki On the Plurality of Worlds. Por. David K. Lewis, „Możliwości: konkretne światy czy abstrakcyjne obiekty proste?", przeł. Urszula Żegleń, w: Tadeusz SzuBKa (red.), Metafizyka w filozofii analitycznej, Towarzystwo Naukowe KUL, Lublin 1995, s. 155-176. A także fragment (§ 4.1, s. 8491) jego wcześniejszej książki (David K. Lewis, Counterfactuals, Basil Blackwell, Oxford 1973): por. David K. Lewis, „Światy możliwe”, przeł. Urszula Żegleń, w: SzuBKa (red.), Metafizyka w filozofii analitycznej..., s. 127-135.

${ }^{36}$ Historia ta została dobrze opowiedziana w artykule Ernana McMullina, ,Fine-Tuning the Universe?" (artykuł niepublikowany). W tym i następnym akapicie trzymam się McMullinowskiej wersji tej historii.

(Przyp. tłum.) Odsyłacz ten zawiera błąd. Artykuł McMullina ukazał się w 1994 roku w pracy: Mark H. Shale and George W. Shields (eds.), Science, Technology, and Religious Ideas, University Press of America, Lanham 1994, s. 97-125. Plantinga nie sprostował tego też w skróconej,
} 
tego rzekomego problemu, które w ciekawy sposób łączy się z Hawkinga-Collinsa propozycją wielu wszechświatów. ${ }^{37}$ Zdaniem Gutha nie musimy przyjmować, że istnieje więcej niż jeden Wszechświat. Jednakże ten jedyny Wszechświat jest znacznie większy niż obserwowalny Wszechświat o średnicy około 10 miliardów lat świetlnych. Obserwowalny Wszechświat kurczy się do rozmiaru maleńkiego, niemal minuskułowego zakątka całego Wszechświata. Model Gutha był jednak obarczony pewnymi trudnościami. Następcę tego modelu zaproponował Andrei D. Linde. ${ }^{38} \mathrm{~W}$ ramach tego modelu Wszechświat składa się z olbrzymiej liczby miniwszechświatów. Te miniwszechświaty są znacznie większe od naszego obserwowalnego Wszechświata, a w różnych miniwszechświatach realizują się różne warunki początkowe. Istotnie: ,prawa fizyki niskich energii, a nawet wymiarowość czasoprzestrzeni mogą w każdym z tych miniwszechświatów być różne: wymiary, wartości tych stałych, tempo ekspansji i tak dalej". ${ }^{39}$

To, co chcę powiedzieć, można ująć następująco. Rozważmy propozycję Hawkinga-Collinsa z roku 1973 albo nowszą, Lindego. Przypuśćmy dalej, że zasadniczym motywem wysunięcia takich sugestii jest uniknięcie problemu kosmicznych koincydencji. Zgodnie z tymi teoriami w tym, że wartości stałych kosmologicznych (w naszym Wszechświecie) są takie, a nie inne, nie ma nic wartego uwagi, wszystkie bowiem możliwe wartości realizują się w tym czy innym wszechświecie. Oczywiście my, ludzcy obserwatorzy, możemy się znajdować wyłącznie tam, gdzie wartości stałych fundamentalnych są takie, że pozwalają na istnienie życia. Innymi słowy, przyjmijmy, że motywem wysunięcia tych teorii jest to, co Ernan McMullin nazwał „Zasadą Obojętności”. Zasadę Obojętności trudno wyrazić w sposób ścisły, ale jej zasadniczą część stanowi idea, że teo-

dwuczęściowej wersji tego artykułu, która ukazała się w 1997 roku w czasopiśmie Origins \& Design (część 1 - vol. 18, no. 1, s. 18-27; część 2 - vol. 18, no. 2, s. 22-34).

${ }^{37}$ Por. Alan H. Guth, „Inflationary Universes: A Possible Solution to the Horizon and Flatness Problems", Physical Review D 1981, vol. 23, no. 2, s. 347-356.

${ }^{38}$ Por. Andrei D. Linde, „The Inflationary Universe”, Reports on Progress in Physics 1984, vol. 47, no. 8, s. 925-986 oraz Andrei D. Linde, „Particle Physics and Inflationary Cosmology”, Physics Today 1987, vol. 40, no. 9 s. 61-68.

${ }^{39}$ Linde, „Particle Physics...”, s. 68. 
ria fizyczna powinna unikać wszystkiego, co przypomina kosmiczne koincydencje, widoczne subtelne zestrojenia, które milcząco wskazują na projekt.

Sądzę, że teista w ogóle nie musi być pod wrażeniem tej zasady. Jeśli Bóg stworzył świat, to dlaczego nie miałyby się w nim przejawiać tego rodzaju osobliwości lub „koincydencje”? Dlaczego mielibyśmy sądzić, że dopóki nie pozbędziemy się takich rzeczy, nie będziemy dysponować trafną teorią fizyczną? Gdyby jakieś dwie teorie były empirycznie równoważne (lub w przybliżeniu równoważne), a pierwsza pociągałaby za sobą pogwałcenie Zasady Obojętności, druga zaś - postulowanie nieskończenie wielu różnorodnych wszechświatów albo olbrzymiej liczby miniwszechświatów, to przez wzgląd na ekonomię teista powinien preferować tę pierwszą. Oczywiście niezależne dane empiryczne mogą obecnie (lub wkrótce) przemawiać na rzecz tej drugiej hipotezy — to znaczy niezależne od Zasady Obojętności. Nawet gdyby jednak tak było, to epistemiczne prawdopodobieństwo teorii wielu wszechświatów w stylu Hawkinga wraz z potwierdzającymi ją świadectwami empirycznymi może się znacznie różnić w zależności od tego, czy przyjmiemy teizm, czy naturalizm.

Mamy zatem trzy przykłady: każdy z nich ukazuje, że teorie naukowe często nie są, w określony sposób, religijnie lub metafizycznie neutralne. Jak dotąd, wskazaliśmy również trzy sposoby, w jakie teoria naukowa może zostać istotnie powiązana z twierdzeniami teologicznymi lub religijnymi, charakterystycznymi dla religii teistycznych. Po pierwsze, teoria naukowa może być niezgodna z tymi twierdzeniami. Po drugie, może być tak, że prawdopodobieństwo teorii naukowej w zestawieniu $\mathrm{z}$ tymi twierdzeniami jest całkowicie różne od prawdopodobieństwa tej teorii $\mathrm{w}$ zestawieniu ze światopoglądem naturalistycznym. Po trzecie, ujęcia religijne lub teologiczne mogą pomóc w określeniu tego, co wymaga wyjaśnienia. Naturalnie można podać znacznie więcej przykładów teorii naukowych, które wiążą się ze wspomnianymi twierdzeniami teologicznymi lub religijnymi na sposoby omówione powyżej (a w ramach nauk o człowieku takie przykłady będą jeszcze oczywistsze i liczniejsze niż w fizyce czy chemii). Muszę tutaj podkreślić dwie rzeczy. Interesuje mnie nauka i naukowe hipotezy rozumiane jako próby dostarczenia nam prawdy: prawdziwych wyjaśnień, prawdziwych opisów, prawdziwych przyczyn rozmaitych zjawisk. Interesuje mnie Simonowskie wyjaśnienie altruizmu rozumiane jako propozycja hipotezy prawdziwej (lub bliskiej prawdy), to samo tyczy się teorii ewolucji oraz rozmaitych 
propozycji teorii wielu wszechświatów lub teorii Wszechświata inflacyjnego. Oczywiście teorii tych nie trzeba tak interpretować. Jeśli zamiast tego myślimy o nauce i jej celach w sposób, w jaki czyni to na przykład Bas van Fraassen, ${ }^{40}$ to cała sytuacja wygląda zgoła inaczej. Dlatego możemy na przykład sądzić, że cała wielka opowieść ewolucji jest wątpliwa, daleka od prawdy, lecz dobrze zachowuje zjawiska i należycie wywiązuje się z innych zadań, jakich oczekuje się od teorii tego typu. Nawet z perspektywy realizmu Wielki Mit Ewolucji nie musi być prawdopodobny, by uznać go za drogowskaz dalszych badań, źródło hipotez czy środek do lepszego zrozumienia przedmiotu badań, o którym traktuje. Sądzimy, że mechanika newtonowska, ściśle biorąc, jest fałszywa, lecz mimo to przydatna in excelsis.

Inna możliwość polega na tym, że zamiast uznawać pewne dziedziny nauki — jak na przykład socjobiologię — za dostarczające prawdziwych czy trafnych wyjaśnień ludzkich zachowań, jedynie sprawdzalibyśmy, jak daleko możemy się posunąć w wyjaśnianiu człowieka i jego zachowania bez odwoływania się do czegokolwiek innego niż to, to do czego byłby skłonny odwoływać się naturalista. ${ }^{41} \mathrm{~W}$ takim wypadku nasze podejście miałoby charakter raczej hipotetyczny niż kategoryczny: przypuśćmy, że naturalizm jest prawdziwy. Jakiego rodzaju wyjaśnienie moglibyśmy znaleźć dla, powiedzmy, altruistycznego zachowania człowieka? (Naturalista na tej samej zasadzie mógłby podchodzić do takiego problemu: załóżmy, że teizm jest prawdziwy; jakie byłoby w takim razie właściwe wyjaśnienie, powiedzmy, agresywnego czy wojowniczego zachowania człowieka?) Nie znam żadnego powodu, by sądzić, że teizm mógłby uznać takie podejście za wartościowe, z wyjątkiem tego, że chrześcijanin może uważać, iż lepszym sposobem spędzania czasu jest, na przykład, odkrywanie prawdziwych naukowych wyjaśnień zachowania się człowieka.

\footnotetext{
${ }^{40}$ Por. np. Bas van Fraassen, Quantum Mechanics: An Empiricst View, Clarendon Press, Oxford 1991, s. 1-4. Takie spojrzenie na pewno jest atrakcyjne, jeśli chodzi o twierdzenia dotyczące niezwykłego świata kwarków i gluonów, a także o historię Wszechświata podczas pierwszych $10^{-32}$ sekund.

${ }^{41}$ Por. William Hasker, „Evolution and Alvin Plantinga”, Perspectives on Science and Christian Faith 1992, vol. 44, no. 3, s. 158-159 oraz przyp. 16 [150-162].
} 


\section{Słabe argumenty na rzecz naturalizmu metodologicznego}

W świetle tych i wielu podobnych przykładów (oraz szerszych rozważań w duchu augustiańskim) naturalnie nasuwa się wniosek, że (przynajmniej w zasadzie) chrześcijańska wspólnota uczonych powinna uprawiać naukę lub pewne jej obszary na swój własny sposób i z własnej perspektywy. Tym, czego naprawdę potrzeba społeczności chrześcijan jest nauka, która bierze pod uwagę to, co wiemy jako chrześcijanie. W każdym razie wydaje się to racjonalne: jest bowiem racjonalne, by podczas wyjaśniania danego zjawiska uwzględniać wszystko, co wiemy. Lecz czy wówczas chrześcijańscy psychologowie nie powinni w ramach naukowego wyjaśniania na przykład wrogości lub agresji zrobić użytku z pojęcia grzechu? Czy poszukując na przykład naukowego wyjaśnienia miłości w jej wielu różnorodnych sposobach wyrażania się albo zabawy, muzyki, humoru czy naszego ducha przygody, nie powinniśmy wziąć pod uwagę także tego, co wiemy o człowieku stworzonym na obraz i podobieństwo Boga, gdyż właśnie On Sam jest źródłem miłości, piękna i tym podobnych? Czyż to samo nie odnosi się do moralności? Weźmy zakrojony na wielką skalę, imponujący oraz fatalny w skutkach eksperyment, jaki przeprowadzili bolszewicy w dwudziestym wieku, który jest być może najwyraźniejszym znamieniem dwudziestowiecznego krajobrazu politycznego. Czyż podczas naukowego wyjaśniania tego eksperymentu chrześcijanie nie powinni posłużyć się wszystkim, co wiedzą o człowieku, włączywszy to, co wiedzą dzięki wierze?

Co prawda, na drodze do tego celu mogą wyłonić się przeszkody o charakterze praktycznym. Zasadniczo jednak, abstrahując od tych praktycznych trudności (które, nawiasem mówiąc, mogą się okazać nie tak groźne, na jakie wyglądają - jak w przysłowiu ,pies, który dużo szczeka, nie gryzie”), właściwa dla wspólnoty chrześcijańskiej droga osiągnięcia naukowego zrozumienia, powiedzmy, sposobu bycia i zachowania się człowieka, rozpoczyna się od tego, co wiemy o człowieku, włączywszy to, co wiemy dzięki wierze. A więc typy hipotez, które badamy, mogą oczywiście dotyczyć takich faktów (jak uważa chrześcijanin) jak ten, że Bóg stworzył nas, ludzi, na Swój obraz i podobieństwo, a my popadliśmy w grzech. Te „religijne” idee mogłyby znaleźć miejsce w naszej nauce $\mathrm{w}$ formie rozmaitych hipotez wprowadzanych explicite. Mogą także pełnić inne role: mogłyby na przykład stanowić część wiedzy uzupełniającej 
(background information), w odniesieniu do której oceniamy rozmaite naukowe hipotezy i mity, jakie pojawiają się na naszej drodze.

Sądzę, że taki sposób myślenia jest czymś zupełnie naturalnym. Dziwi jednak, że powszechnie bierze się za pewnik negację tego twierdzenia. W istocie zyskała ona status filozoficznej ortodoksji. Pośród tych, którzy sprzeciwiają się temu twierdzeniu, są myśliciele chrześcijańscy o imponujących kwalifikacjach. Oto, co pisze na ten temat Ernan McMullin:

Lecz oczywiście naturalizm metodologiczny nie ogranicza naszych badań przyrody określa po prostu, jaki rodzaj badań uznaje się za naukowy. Jeśli ktoś chce próbować innego podejścia do badania przyrody - a jest wiele innych — to naturalista metodologiczny nie ma żadnego powodu, by się temu sprzeciwiać. Naukowcy musza postępować w ten sposób. Metodologia nauk przyrodniczych nie daje żadnego punktu oparcia dla twierdzenia, że konkretne zdarzenie lub typ zdarzeń należy wyjaśniać przez odwołanie się do bezpośredniego Boskiego aktu stwórczego. ${ }^{42}$

Oczywiście część tego problemu polega na jaśniejszym zrozumieniu, czym jest ów naturalizm metodologiczny. Do czego dokładnie się on sprowadza? Czy nakłada embargo wyłącznie na twierdzenia, takie jak to, że konkretne zdarzenie należy wyjaśniać, odwołując się bezpośrednio do Boskiego aktu stwórczego pomijającego udział ,przyczyn wtórnych”? Czy naturalizm metodologiczny zakazuje w wyjaśnianiu naukowym odwoływania się również do pośrednich Boskich aktów stwórczych? Czy odnosi się wyłącznie do naukowych wyjaśnień, ale nie do innego rodzaju twierdzeń naukowych? Czy wyklucza również wykorzystywanie twierdzeń o Boskich aktach stwórczych lub innych twierdzeń religijnych jako części wiedzy zastanej, w odniesieniu do której próbuje się ocenić prawdopodobieństwo jakiegoś zaproponowanego naukowego wyjaśnienia lub ujęcia? Kwestiom tym będziemy musieli się przyjrzeć później. Teraz chciałbym rozpatrzyć inne pytanie: jakie racje stoją za akceptacją twierdzenia, że nauka faktycznie pociąga za sobą tego typu - cokolwiek dokładnie przezeń rozumiemy naturalizm metodologiczny? Przeanalizuję pewne zaproponowane racje na rzecz tego twierdzenia i wykażę, że są niewystarczające. Następnie będę argumentował, że mimo to za tym twierdzeniem przynajmniej częściowo przemawia kilka

\footnotetext{
${ }^{42}$ McMullin, „Plantinga’s Defence...”, s. 57.
} 
bardzo sensownych racji. Jednakże racje te nie wspierają tezy, że nauka jest religijnie neutralna.

Jaką podstawę ma zatem idea, że nauka w pewien sposób nieodzownie wymaga tej zasady naturalizmu metodologicznego? Po pierwsze i być może najważniejsze: ta koncepcja nauki stanowi integralną i gruntowną część całej koncepcji wiary i rozumu, którą odziedziczyliśmy po Oświeceniu. Nie miejsce tu na potraktowanie tego tematu w sposób tak wyczerpujący, jak na to zasługuje, lecz kluczowa idea polega na tym, że nauka jest obiektywna, publiczna, wspólnotowa, publicznie sprawdzalna i równie dostępna każdemu, niezależnie od nastawień religijnych lub metafizycznych. Można być buddystą, hinduistą, protestantem, katolikiem, muzułmaninem, żydem, bahaitą lub nie należeć do żadnej z wymienionych religii: zdobycze nauki pozostają jednakowe dla nas wszystkich. Jest tak dlatego, że rzetelna nauka, jak rozumiano ją w Oświeceniu, ogranicza się do werdyktu rozumu i zmysłów (percepcji), które są takie same dla wszystkich ludzi. Religia jest zaś prywatna, subiektywna i w oczywisty sposób podatna na znaczące indywidualne różnice. W takim razie jeśli nauka rzeczywiście jest publiczna i wspólna dla wszystkich, to oczywiście nie można jej należycie uprawiać, gdy punktem wyjścia są w jakiejś mierze przekonania lub dogmaty religijne.

Jedno ze źródeł takiego sposobu myślenia o nauce wypływa z nowożytnego fundacjonizmu wywodzącego się od Kartezjusza, a być może bardziej nawet od Locke'a. Ostatnimi czasy nowożytny klasyczny fundacjonizm został poddany poważnej krytyce, a ja nie zamierzam zabierać głosu w całej tej wrzawie. ${ }^{43}$ A ponieważ klasyczny fundacjonizm, na którym opiera się naturalizm metodologiczny, osiadł na mieliźnie, rozważę w zamian kilka bardziej lokalnych, mniej okazałych i kosmicznych, racji na rzecz przyjęcia naturalizmu metodologicznego.

${ }^{43}$ Argumentowałem gdzie indziej, że jeden z warunków racjonalności, na którym opiera się nowożytny klasyczny fundacjonizm, w rzeczywistości jest niespójny, ponieważ jest uwikłany w paradoks samoodniesienia. Por. np. Alvin Plantinga, „Reason and Belief in God”, w: Alvin Plantinga and Nicholas Wolterstorff (eds.), Faith and Rationality: Reason and Belief in God, University of Notre Dame Press, Notre Dame, Indianapolis 1983, s. 60 i n. [16-93]. 


\section{Naturalizm metodologiczny jest prawdziwy z definicji}

Dlaczego naukowiec musi postępować zgodnie z naturalizmem metodologicznym? Michael Ruse sugeruje, że naturalizm metodologiczny, a w każdym razie jego część, jest prawdziwy z definicji:

Co więcej, nawet gdyby kreacjonizm naukowy odniósł całkowity sukces, naukowo dowodząc swojej słuszności, to nie dostarczyłby naukowego wyjaśnienia genezy. Mógłby dowieść co najwyżej tego, że nauka pokazuje, iż nie może być żadnego naukowego wyjaśnienia genezy. Kreacjoniści wierzą, że świat powstał w wyniku cudu. Ale cudy znajdują się poza obszarem nauki, która z definicji dotyczy wyłącznie tego, co naturalne, powtarzalne, podlega prawu. ${ }^{44}$

Ruse sugeruje, że naturalizm metodologiczny jest prawdziwy na mocy przyjętej definicji terminu „nauka”. Najwyraźniej utrzymuje on, że istnieje adekwatna definicja „nauki”, taka, z której treści wynika, że nauka traktuje wyłącznie o tym, co jest naturalne, powtarzalne i podlega prawu. (Zauważmy, że twierdzenie to nie rzutuje na sugestie, iż naukowiec chrześcijanin może wysuwać hipotezy obejmujące takie ,religijne” doktryny jak na przykład grzech pierworodny, a także oceniać epistemiczne prawdopodobieństwo hipotez naukowych względem przekonań uzupełniających [background belief], do których zaliczają się także przekonania chrześcijańskie.) Twierdzenie Ruse'a najwyraźniej wyklucza hipotezy, które zawierają odniesienie do Boga. Bóg jest istotą nadnaturalną, dlatego hipotezy odnoszące się do Boga traktują o czymś ponad tym, co naturalne. W związku z tym hipotezy takie nie mogą być częścią nauki.

Twierdzenie Ruse'a ma trzy szczególnie osobliwe aspekty. Po pierwsze, przynajmniej od kilku stuleci poświęcono wielkie nakłady energii tak zwanemu problemowi demarkacji: problemowi sformułowania warunków koniecznych i wystarczających odróżnienia nauki od innych sfer działalności człowieka. ${ }^{45}$ Próba ta najwyraźniej zupełnie się nie powiodła, ale gdyby faktycznie była jakaś definicja w rodzaju tej, do jakiej odwołuje się Ruse, to przypuszczalnie istniałby

\footnotetext{
${ }^{44}$ Ruse, Darwinism Defended..., s. 322 [wyróżnienia dodane].

${ }^{45}$ Por. np. Larry Laudan, „Zgon problemu demarkacji”, przeł. Artur Koterski, w: Zbysław MusZYŃsKi (red.), Z badań nad prawdą, nauką i poznaniem, Realizm. Racjonalność. Relatywizm, t. 31, Wydawnictwo UMCS, Lublin 1998, s. 63-79.
} 
zbiór warunków koniecznych i wystarczających dla czegoś, co nazywamy nauką. Sądzę, że Ruse nie przytacza wielu mocnych argumentów na rzecz wniosku, że nie ma żadnego takiego zbioru warunków koniecznych i wystarczających, nie wspominając już o takowej definicji terminu „nauka”. Po prostu oświadcza, że nauka „z definicji” posiada wymienione przez niego własności.

Po drugie, Ruse wskazuje na trzy własności, które, jak twierdzi, z definicji charakteryzują każdy fragment nauki. Cała nauka traktuje o tym, co (a) powtarzalne, (b) wyłącznie naturalne i (c) podlega prawu przyrody. Weźmy zatem powtarzalność. Rozważmy następujący fragment artykułu Andreia Lindego, w którym wypowiadając się o Wielkim Wybuchu, mówi: „można uznać, że bardzo trudno jest pozyskać użyteczne i wiarygodne informacje z unikalnego eksperymentu, przeprowadzonego około $10^{10}$ lat temu". ${ }^{46}$ Zdaniem Lindego Wielki Wybuch jest unikalny i dlatego prawdopodobnie niepowtarzalny — w każdym razie może się okazać, że jest niepowtarzalny. Jeśli tak, to czy musimy uznać, że współczesne kosmologiczne badania natury Wielkiego Wybuchu oraz wczesnego stadium rozwoju Wszechświata naprawdę nie są częścią nauki?

Rozważmy dalej własność podlegania prawu. Pierwszy krok polegałby tu na stwierdzeniu, że samo istnienie praw przyrody jest kontrowersyjne. Przykładowo Bas van Fraassen przedstawił pewien rozbudowany i wywierający duże wrażenie argument na rzecz wniosku, że nie istnieją żadne prawa przyrody. ${ }^{47} \mathrm{Oczy}-$ wiście istnieją regularności, ale regularność nie jest jeszcze prawem. Prawo bowiem ma tę regularność wyjaśniać i uzasadniać. Ponadto prawo ma być związane z pewnego rodzaju koniecznością, którą zazwyczaj rozumie się mniej rygorystycznie niż szeroko rozumianą konieczność logiczną, ale i tak jest to konieczność. ${ }^{48}$ Sądzę, że ta idea podlegania prawu stanowi dziedzictwo oświeceniowego deizmu (por. s. 39 tego artykułu), a w tym wypadku, podobnie jak w wielu innych, oświeceniowy deizm przypuszczalnie jest nietrafny. Być może nie da się spełnić wymogów uznania jakiejś zależności za prawo przyrody. Możliwe,

\footnotetext{
${ }^{46}$ LindE, „Particle physics...”, s. 61.

${ }^{47}$ Por. Bas van FraAssen, Laws and Symmetry, Oxford University Press, Oxford 1989, rozdz. 2-5.

${ }^{48}$ Por. np. David M. Armstrong, What is a Law of Nature?, Cambridge Studies in Philosophy, Cambridge University Press, Cambridge 1983, s. 39 i n.
} 
że istnieją regularności, ale nie prawa. Możliwe, że nie ma niczego takiego jak konieczność rzekomo nieodłącznie związana z prawami. Być może najlepszym sposobem myślenia o tych domniemanych prawach jest ujęcie ich jako uniwersalnie lub niemal uniwersalnie skwantyfikowane nierzeczywiste okresy warunkowe wolności Bożej. ${ }^{49}$ Przyjmijmy zatem, że van Fraassen ma rację i nie istnieją żadne prawa przyrody: czy na mocy definicji wynika z tego, że nie istnieje żadna nauka? Twierdzenie to wydaje się trochę za mocne. Poza tym, na podstawie tego, co wiemy, możemy stwierdzić, że jakieś prawa istnieją, ale nie wszystko im podlega (lub nie podlega im całkowicie). Być może właśnie tak jest z trzęsieniami ziemi, pogodą i rozpadem promieniotwórczym. Czy wynikałoby $\mathrm{z}$ tego, że tych rzeczy nie da się badać naukowo?

Trzeci problem dotyczący twierdzenia Ruse'a polega na tym, że trudno wyobrazić sobie, jak przez odwołanie się do określonej definicji można by rozstrzygnąć poważny spór o to, co jest, a co nie jest nauką. Można by uznać, że to zasadne, wyłącznie gdyby pierwotne pytanie w rzeczywistości miało charakter werbalny - gdyby było pytaniem w rodzaju: czy polskie słowo „,nauka” w sposób poprawny stosuje się do hipotezy, która odwohuje się do Boga? Pytanie jednak było inne. Brzmi ono: czy hipoteza, która odnosi się do Boga, może być częścia nauki? Na to pytanie nie można odpowiedzieć, po prostu przytaczając definicję.

Pozwolę sobie roztrząsać tę kwestię dalej. Definicja terminu „nauka” byłaby wyjaśnieniem tego, co termin ten oznacza - w języku polskim lub czyimś idiolekcie. Weźmy drugi przypadek: możliwe, że Ruse używa terminu „nauka” zgodnie z pewną definicją, w świetle której nie stosuje się go do hipotez zawierających odniesienia do Boga. Lecz oczywiście sama ta konstatacja ma niewielki wpływ na odpowiedź na pytanie, które my wyrażamy w zdaniu: „czy hipoteza naukowa może zawierać odniesienie do Boga?", chyba że używamy tego terminu zgodnie z tą samą lub podobną definicją. Ale tak nie czynimy. Gdyby tak było, pytanie to okazałoby się trywialne, jak pytanie, czy istnieją żonaci kawale-

\footnotetext{
${ }^{49}$ To znaczy sądy wyrażające, jak Bóg (w sposób wolny) traktuje swoje stworzenie oraz jak traktowałby je, gdyby stworzenie różniło się w sposób istotny. „Niemal uniwersalnie skwantyfikowane" oznacza: jeśli myślimy o nich w ten sposób, to możemy myśleć, że cudy zachodzą wbrew prawu, nie uznając ich (niekonsekwentnie) za odstępstwa od pewnego sądu o charakterze uniwersalnym i koniecznym.
} 
rowie. $\mathrm{Z}$ drugiej strony być może zdanie, o które chodzi, jest prawdziwe na mocy definicji terminu w języku polskim (nie w idiolekcie Ruse'a). Idea ta polegałaby na tym, że znaczenie terminu ,nauka” w języku polskim może być podane $\mathrm{z}$ definicji, a zgodnie $\mathrm{z}$ tą definicją termin ,nauka” w poprawny sposób stosuje się do hipotezy, wyłącznie jeśli ta hipoteza nie zawiera odniesień do Boga. Ale czy rzeczywiście może tak być? Weźmy pod uwagę tych, którzy podążając za Kuyperem i Augustynem, sądzą, że chrześcijanie, uprawiając naukę, powinni otwarcie uwzględniać to, co wiedzą dzięki wierze. Czy ta idea sprowadza się do tego, że z jakiegoś powodu nie udało im się nauczyć poprawnego sposobu użycia tego terminu w języku polskim (lub terminów pokrewnych w słoweńskim lub łacinie)? To bardzo wątpliwe.

Lecz nawet jeśli z definicji byłoby prawdą, że hipotezy naukowe nie mogą zawierać żadnych odwołań do Boga, to nie wynikałoby z tego nic szczególnie interesującego. Augystyni i Kuyperowie tego świata musieliby wówczas przyznać się do popełnienia błędu. Lecz błąd ten miałby co najwyżej charakter werbalny. Musieliby przyznać, że wyrażając swoje poglądy lub zadając pytania, nie potrafią poprawnie posługiwać się terminem ,nauka”. Musieliby posłużyć się jakimś innym terminem, takim jak „nałka” (który wymawia się tak samo jak termin „nauka”). Definicja „nałki” wywodzi się z definicji „nauki”, usunąwszy z tej ostatniej klauzulę zakazującą hipotez zawierających odniesienia do Boga (to jest usunąwszy z przyjmowanej przez Ruse'a definicji terminu „nauka” klauzulę, zgodnie z którą nauka traktuje wyłącznie o tym, co naturalne). Błąd ludzi pokroju Augustyna i Kuypera nie tkwiłby w tym, co mówią, lecz raczej w tym, jak to mówią.

Sądzę, że prawdziwe pytanie dotyczy czegoś zupełnie innego. Termin „nauka" oznacza ważną formę działalności człowieka. Podanie (bogatych w treść) warunków koniecznych i wystarczających charakteryzujących tę działalność jest trudne lub zgoła niemożliwe. Nie da się powiedzieć, gdzie dokładnie kończy się nauka, a zaczyna coś innego (wiedza potoczna, metafizyka, epistemologia, religia). Możemy jednak opisywać paradygmaty nauki, a także powiedzieć coś pouczającego o tym, co zazwyczaj lub często charakteryzuje naukę. Tak więc przykładowo działalność ta charakteryzuje się wymogiem obserwacji i eksperymentu (czasami „eksperymentów myślowych” w odróżnieniu od eksperymentów rzeczywiście przeprowadzonych). Często będzie to również odnoszenie się 
do czegoś, co opisuje się jako prawo (lub nazywa się prawem), chociaż naleganie, aby to „prawo” było czymś więcej niż regularnością, nie stanowi części omawianej działalności. Taki paradygmat charakteryzuje się także tym, że prowadzi do testowalnych przewidywań. ${ }^{50}$ Jest to cecha paradygmatycznych przykładów tej działalności, której opisanie jest niewdzięcznym zadaniem, ale oczywiście niekoniecznie cecha wszystkich przykładów (a elementy, które nie posiadają tej cechy — na przykład McMullinowska Zasada Obojętności — mogą być głęboko wplecione w naukę jako pewien horyzont, stałe kontekstowe tło, stałe założenie). Weźmy na przykład teorię superstrun przedstawioną przez Schwarza i Greena na początku lat osiemdziesiątych dwudziestego wieku. Najwyraźniej teoria ta funkcjonuje wyłącznie w 10 wymiarach, jeśli więc jest prawdziwa, to powstaje pytanie: co się stało z pozostałymi sześcioma? „Uznaje się, że pozostałe wymiary zostały zwinięte do skali długości Plancka $\left(10^{-33} \mathrm{~cm}\right)$, tak małej, że — nieważne, jak byśmy się starali — nigdy nie będziemy w stanie przyjrzeć się im za pośrednictwem naszych mikroskopów lub zderzaczy cząstek". ${ }^{51}$

Możemy przeto dowiedzieć się całkiem sporo o tej formie działalności człowieka, opisując, jak funkcjonuje nauka. A jest to działalność o ogromnej wartości i znaczeniu. Ma olbrzymią wartość praktyczną, której rezultatem jest zwiększenie się długości życia, uwolnienie od wielu chorób, wzrost komfortu i jakości życia wielu ludzi. (Dostarczyła nam także środków do zniszczenia nas samych i naszego środowiska.) Jednak korzyści, jakie z niej czerpiemy, bynajmniej nie są jedynie praktyczne. Współczesna nauka umożliwiła nam także nauczenie się wiele o nas samych i świecie stworzonym przez Boga. Trudno nawet sobie wyobrazić, jak wyglądało życie intelektualne przed powstaniem nauki. Oprócz tego pewne obszary nauki - na przykład fizykę teoretyczną — cechują doskonałe, surowe wewnętrzne piękno i siła. Owe obszary reprezentują wspaniałe, imponujące dokonania intelektualne. Przypominają wielką poezję i wielką muzykę. Być może najdonioślejszym osiągnięciem intelektualnym ludzkości jest fizyka teoretyczna od, powiedzmy, Newtona do dnia dzisiejszego. A zatem pytanie brzmi:

\footnotetext{
${ }^{50}$ Być może warto zwrócić uwagę, że wiele hipotez, w ramach których wspomina się o Bogu, jest wysoce testowalnych: na przykład hipoteza, że Bóg stworzył króliki ważące półtorej tony i żyjące w Wąchocku.

${ }^{51}$ Marc DAvIS, „Cosmology: The Modern Creation Myth”, Bulletin of the American Academy of the Arts and Sciences 1992, vol. 45, no. 8, s. 62 [47-64].
} 
czy chrześcijanie powinni kontynuować to przedsięwzięcie z perspektywy chrześcijańskiej? Czy charakter tego przedsięwzięcia wskazuje, że perspektywa religijna lub teologiczna jest dlań odpowiednia? Nie uzyskamy odpowiedzi na to pytanie wyłącznie na podstawie definicji słowa „nauka”. Odpowiedź będzie wymagała obeznania $\mathrm{z}$ tą działalnością oraz wnikliwości niezbędnej, by dostrzec cechy, które tę działalność charakteryzują. Będzie wymagała więc fundamentalnych pytań o naturę nauki, naszą własną naturę, a także naturę świata, w jakim żyjemy.

\section{Czy ,funkcjonalna integralność" wymaga naturalizmu metodologicznego?}

Odpowiedzi w tym duchu udzielają Diogenes Allen, John Stek i Howard Van Till. Według tego ostatniego Bóg stworzył świat, który charakteryzuje „funkcjonalna integralność”:

Terminem tym oznaczam stworzony świat, który nie posiada żadnych funkcjonalnych niedoskonałości. To jest nie posiada we własnej ekonomii żadnych luk takiego rodzaju, że wymagałyby, aby Bóg działał bezpośrednio, tymczasowo przyjmując rolę stworzenia, pełniąc takie funkcje wewnątrz ekonomii stworzonego świata, do których inne stworzenia nie zostały przygotowane. ${ }^{52}$

Zwróćmy najpierw uwagę, że Van Till wydaje się kierować ogień krytyki tylko na jeden spośród kilku sposobów, na jakie chrześcijanie, uprawiając naukę, mogą wykorzystać to, co wiedzą dzięki wierze. Van Till argumentuje, że hipoteza naukowa nie może w sposób właściwy głosić, że Bóg czyni coś bezpośrednio. (Zauważmy także, że nie twierdzi się tutaj, iż taka hipoteza byłaby nienaukowa, lecz że byłaby fatszywa.) To, co mówi, wydaje się zgodne, na ile mogę się wypowiedzieć, z twierdzeniem, że (powiedzmy) chrześcijańscy psychologowie w ramach swojej dziedziny mogą zasadnie odwołać się do faktu, że ludzie zostali stworzeni na obraz i podobieństwo Boga albo że są obarczeni grzechem pierworodnym.

\footnotetext{
${ }^{52}$ Howard J. VAN TILl, „When Faith and Reason Cooperate”, Christian Scholar's Review 1991, vol. 21 , no. 1 , s. 42 [33-45].
} 
Przypuśćmy więc, że przystajemy na zaproponowany przez Van Tilla zakaz hipotez, z których wynika, że Bóg dokonał czegoś bezpośrednio. Ta idea bezpośredniego działania skrywa problemy i zasługuje na większą uwagę niż mogę jej poświęcić w tym artykule. ${ }^{53}$ Jednak zasadnicza idea jest dość jasna. Przykładem pośredniego Boskiego stwarzania byłoby wybudowanie domu przeze mnie. Możemy powiedzieć, że to Bóg stwarza dom, lecz czyni to pośrednio, traktując moje działanie jako środek. Bóg działa więc pośrednio, jeśli wywołuje pewien skutek za pośrednictwem działania czegoś, co stworzył. Natomiast bezpośrednio działa wtedy i tylko wtedy, gdy wywołuje pewien skutek i nie czyni tego za pomocą działania jakiejś istoty, którą stworzył.

Van Till sugeruje zatem, że Bóg w ogóle nie dokonuje niczego w świecie bezpośrednio. Wyłącznie stworzenia robią wszystko bezpośrednio. Ale bez wątpienia Van Till, podobnie jak inni teiści, zgodziłby się, że Bóg bezpośrednio zachowuje w istnieniu świat oraz swoje stworzenia, że jest On bezpośrednio obecny w Wielkim Wybuchu, lecz także w upadku wróbla. Gdyby Bóg zawiesił to stałe zachowujące działanie, świat rozwiałby się niczym sen po przebudzeniu. Bez wątpienia Van Till zgodziłby się również (pod groźbą regresu w nieskończoność), że jeśli Bóg czyni cokolwiek w świecie pośrednio, to czyni też coś bezpośrednio. Przypuszczalnie bowiem Bóg nie może spowodować skutku pośrednio, obywszy się w jakimś punkcie także bez działania bezpośredniego, bez stwarzania czegoś bezpośrednio. Dlatego Van Tilla należy rozumieć w jakiś inny sposób. Być może jego idea polega na tym, że Bóg stworzył Wszechświat w pewnym momencie w przeszłości (działając wówczas bezpośrednio), lecz odtąd nigdy nie działa w świecie bezpośrednio, za wyjątkiem zachowywania w istnieniu swojego stworzenia oraz cudów związanych z historią zbawienia. Ale dlaczego mamy tak to ujmować? Czy zważywszy na fakt, że tak różniący się od siebie chrześcijanie jak papież Pius XII i Jan Kalwin sądzili, że Bóg stwarza ludzkie dusze bezpośrednio, możemy po prostu przyjąć bez żadnego argumentu, że się mylili? Co uzasadnia przypuszczenie, że Bóg nie działa już bezpośrednio w świecie?

\footnotetext{
${ }^{53}$ Por. np. William P. Alston, „Divine and Human Action”, w: Thomas V. Morris (ed.), Divine and Human Action: Essays in Metaphysics of Theism, Cornell University Press, Ithaca 1988, s. 257-280.
} 
Van Till szuka wsparcia dla swego teologicznego stanowiska u Diogenesa Allena i Johna Steka. Allen utrzymuje, że:

Pojęcie Boga nigdy nie może być w sposób poprawny użyte w wyjaśnieniach naukowych, które formułuje się za pomocą relacji pomiędzy elementami Wszechświata, ponieważ zredukowałoby to Boga do statusu stworzenia. Zgodnie z chrześcijańską koncepcją Boga jako Stwórcy Wszechświata, który jest na wskroś racjonalny, nie ma żadnych brakujących relacji pomiędzy elementami przyrody. Jeśli w naszych badaniach przyrody napotkamy coś, co wydaje się stanowić przykład brakującego połączenia pomiędzy elementami Wszechświata, to chrześcijańska doktryna stworzenia sugeruje, że powinniśmy poszukiwać dalej. ${ }^{54}$

Allen najwyraźniej daje do zrozumienia nie tylko, że chrześcijanie nie mogą w sposób właściwy — jako część nauki — oświadczyć, że Bóg dokonał czegoś bezpośrednio, lecz także iż $\mathrm{w}$ ramach nauki odwoływanie się do idei w rodzaju tej, że ludzie zostali stworzeni na obraz i podobieństwo Boże, oznaczałoby wykroczenie poza porządek nauki. Idea ta bowiem nie sprowadza się do opisania, w jaki sposób stworzenia w świecie są powiązane ze sobą, lecz do tego, jak pewne stworzenia w świecie - my, ludzie - są związane z Bogiem. Allen jest przekonany, że wyjaśnienia naukowe należy zawsze formułować w odniesieniu do relacji zachodzących między elementami stworzonego Wszechświata (a jeśli to prawda, to, jak twierdzi, możliwe, że w ramach nauki odniesienie do Boga zredukowałoby go do stworzenia). Jednak branie tej sugestii za dobrą monetę wydaje się zbyt pochopne. $Z$ podręcznika astronomii można się dowiedzieć, jaka jest średnica Jowisza (albo jaki jest wiek Ziemi, Słońca czy Drogi Mlecznej). Natomiast nie można się zeń dowiedzieć, w jaki sposób przedmioty w świecie pozostają ze sobą powiązane, chociaż można dowiedzieć się czegoś na temat któregoś z tych przedmiotów. Niemniej jest to nauka.

Oczywiście sedno wypowiedzi Allena sprowadza się do tego, że wyjaśnień naukowych nie można sformułować prawidłowo za pomocą jakichkolwiek odniesień do Boga. Ale dlaczego nie? Jakie jest uzasadnienie tego twierdzenia? Czyż nie wydaje się ono arbitralne? Rozważmy prawdę, że ludzie zostali stworzeni na Boży obraz i podobieństwo, oraz że zgrzeszyli. Ta dwoista prawda

\footnotetext{
${ }^{54}$ Diogenes Allen, Christian Belief in a Postmodern World: The Full Wealth of Conviction, Westminster/John Knox Press, Louisville 1989, s. 45.
} 
może okazać się bardzo użyteczna w formułowaniu psychologicznych wyjaśnień rozmaitych zjawisk. Jeśli tak, to dlaczego chrześcijański psycholog nie powinien jej uwzględniać? Dlaczego taki rezultat nie miałby być naukowy? Mogłoby być tak, że badania sugerowałyby, iż Bóg stworzył życie bezpośrednio, że nie powstało ono za pośrednictwem innych części stworzenia. Jeśli okaże się, że tak się rzeczy mają lub $\mathrm{w}$ danym czasie będzie na to wyglądało, to dlaczego tego nie mówić? I dlaczego nie mielibyśmy uznać tego za twierdzenie naukowe? Jako chrześcijanie wierzymy oczywiście, że Bóg stworzył świat i mógł dokonać tego wieloma różnymi drogami. Dlaczego nie wykorzystać tej wiedzy w ocenie prawdopodobieństwa rozmaitych hipotez (na przykład Wielkiego Mitu Ewolucji)? Chrześcijanie żywią również przekonania o tym, co jest racjonalne w sensie Simona - to jest o tym, do jakiego typu celów będzie dążyć prawidłowo funkcjonująca istota ludzka. A także przekonania co do tego, jakiego typu działania leżą w ich (lub kogoś innego) najlepszym interesie. Czemu nie zastosować tych przekonań oceniając, powiedzmy, prawdopodobieństwo Simonowskiego wyjaśnienia altruizmu albo proponując własne wyjaśnienie tych zjawisk?

Rozważmy na koniec stanowisko Johna Steka:

Ponieważ dziedzina stworzenia jest całkowicie obdarzona swą własną ekonomią, która nie jest ani niepełna (Bóg nie jest jej komponentem), ani wadliwa, w naszym rozumieniu ekonomii tej dziedziny majacym na celu sprawowanie nad nia namiestnictwa rozumieniu opartym zarówno na doświadczeniu praktycznym, jak i przedsięwzięciach naukowych - musimy metodologicznie wykluczyć wszelkie pojęcia bezpośredniej przyczynowości Bożej. Jako namiestnicy stworzenia musimy metodologicznie honorować zasadę, że stworzenie interpretuje stworzenie. Musimy honorować tę zasadę z taką „nabożnością”, z jaką teolog musi honorować zasadę, że „Pismo Święte interpretuje Pismo Święte" - albo — ze względu na to, że Pismo presuponuje objawienie ogólne —że objawienie interpretuje objawienie. Dążąc do namiestniczego zrozumienia stworzenia, nie możemy umieszczać „Boga w lukach wiedzy”, nawet w tak tajemniczej, jak dotąd, dziedzinie cząstek subatomowych. Nie możemy tak postąpić, ponieważ (1) Bóg nie jest wewnętrznym elementem ekonomii stworzenia oraz (2) ponieważ byłaby to zuchwała próba objęcia władzy nad Bogiem - aroganckie szaleństwo właściwe przedstawicielom wielu kultur, którzy twierdzili, że są specjalistami w manipulowaniu boskimi mocami (na przykład szamanom w rosyjskiej religii ludowej lub znachorom w kulturach prymitywnych). ${ }^{55}$

\footnotetext{
${ }^{55}$ John H. STeK, „What Says the Scripture?”, w: Howard J. VAn Till, Robert E. SNow, John H. Stek, and Davis A. Young (eds.), Portraits of Creation: Biblical and Scientific Perspectives
} 
Stek upiera się, że „musimy metodologicznie wykluczyć wszelkie pojęcia bezpośredniej przyczynowości Bożej” z naszego rozumienia ekonomii stworzenia. Jeden z powodów, jakie podaje, sprowadza się do tego, że odwołanie się do pojęcia bezpośredniej przyczynowości Bożej byłoby równoznaczne z umieszczeniem „Boga w lukach wiedzy”, a uczynienie tego to zuchwała próba objęcia władzy nad Bogiem. Ale czy naprawdę usiłuję objąć władzę nad Bogiem, przyjmując na przykład pogląd zbieżny z poglądami Jana Kalwina, papieża Piusa XII i wielu innych, że Bóg bezpośrednio stwarza istoty ludzkie? Albo twierdząc, że stworzył życie w bezpośrednim akcie stwórczym? W najlepszym razie propozycja ta wymaga dalszych argumentów.

Stek twierdzi, że Bóg nie jest wewnętrznym elementem dziedziny stworzenia. $Z$ tego jednak nie wynika, że Bóg nie działa natychmiastowo lub bezpośrednio w dziedzinie stworzenia. Podobnie jak każdy teista, Stek zgodziłby się, że Bóg bezpośrednio zachowuje w istnieniu swoje stworzenie. Czyż nie zgodziłby się również, że jeśli Bóg stwarza cokolwiek pośrednio, to także stwarza coś bezpośrednio? Dlatego nie mam pewności, dlaczego Stek sądzi, że musimy przestrzegać naturalizmu metodologicznego. Dlaczego myśli, że Bóg nie czyni ani nie stwarza niczego w sposób bezpośredni? Jaki ma powód, by tak sądzić? Pismo Święte tego nie sugeruje, nie wydaje się również, aby istniały argumenty pochodzące z innego źródła. Dlaczego więc przyjmuje naturalizm metodologiczny?

Wobec tego argumenty na rzecz konieczności albo celowości naturalizmu metodologicznego nie wydają się mocne. A z racji tego, że $s q$ tak słabe, prawdopodobnie uzasadnione jest podejrzenie, że naprawdę nie odzwierciedlają tego, co dzieje się w umysłach tych, którzy je wysuwają. Sugeruję, że jest pewien inny, niewypowiedziany powód tego posłuszeństwa naturalizmowi metodologicznemu: strach przed teologia Boga w lukach wiedzy oraz odraza do niej. Jak widzieliśmy powyżej, Stek deklaruje, że: „dążąc do namiestniczego zrozumienia stworzenia, nie możemy umieszczać «Boga w lukach wiedzy»”. Stek oraz trzej inni autorzy, których w tym kontekście cytowałem (McMullin, Van Till i Allen), wspominają wprost o teologii Boga w lukach wiedzy oraz wyraźnie łączą ją

on the World's Formation, William B. Eerdmans Publishing Company, Grand Rapids 1990, s. 261 [203-265]. 
z naturalizmem metodologicznym poprzez sugestię, że Bóg uczynił to czy owo bezpośrednio. Najwyraźniej idea ta zasadza się na tym, iż utrzymywanie, że Bóg działa bezpośrednio w obrębie stworzenia, oznacza popadnięcie w taką teologię, a przynajmniej zbliżenie się w jej stronę na niebezpieczną odległość. Ale czy to prawda? Czym dokładnie jest teologia Boga w lukach wiedzy?

Teologia ta nie jest czymś, co da się scharakteryzować doktadnie. Jednak, nieco mgliście, można ją scharakteryzować następująco: rzecznik teologii Boga w lukach wiedzy jest oświeceniowym półdeistą, który sądzi, że Wszechświat jest olbrzymią maszyną, działającą według pewnego zbioru koniecznych i nienaruszalnych praw przyrody. (Możliwe, że Bóg stworzył Wszechświat, lecz jeśli tak uczynił, to obecnie Wszechświat jest w przeważającej części samodzielny i samowystarczalny.) Poza tym prawa przyrody cechuje swego rodzaju wzniosła majestatyczność. Mają charakter konieczny w pewnym mocnym sensie: być może nawet Bóg, jeśli istnieje taka osoba, nie mógłby ich złamać; a nawet jeśli mógłby, to niemal na pewno by tego nie uczynił. Stąd bierze się, niedający się inaczej wytłumaczyć, tak charakterystyczny dla tego sposobu myślenia, lęk przed odwołaniami do cudów.) Nauki przyrodnicze badają i rozkładają na części strukturę tej kosmicznej maszyny, zwłaszcza poprzez próby odkrycia i wyjawienia tych praw oraz wyjaśnienia zjawisk za ich pomocą. Zdaje się, że jednak zachodzą jakieś zjawiska, które opierają się wyjaśnieniom naturalistycznym w każdym razie, jak dotąd. Dlatego powinniśmy postulować istnienie bóstwa, aby, odwoławszy się do jego działania, móc wyjaśnić to, czego nie może wyjaśnić dzisiejsza nauka. Sugestia Newtona, że Bóg okresowo reguluje orbity planet, stanowi taki właśnie często przytaczany przykład teologii Boga w lukach wiedzy.

Zasadnicze cechy teologii Boga w lukach wiedzy są więc następujące. Po pierwsze, świat jest olbrzymią maszyną, która jest niemal całkowicie samowystarczalna. Działanie Boga w przyrodzie ogranicza się do tych zjawisk, dla których nie ma żadnego naukowego, to znaczy: mechanistycznego i naturalistycznego, wyjaśnienia. Po drugie, istnienie Boga jest pewnego rodzaju hipotezą o bardzo szerokim zakresie, postulowaną w celu wyjaśnienia tego, czego nie 
można wyjaśnić w inny sposób, to jest naturalistycznie. ${ }^{56}$ Po trzecie, jest jeszcze akcent apologetyczny: najlepszym lub jednym z najlepszych powodów, by wierzyć, że istnieje taka osoba jak Bóg, jest fakt, że istnieją zjawiska, których nauki przyrodnicze (jak dotąd) nie potrafią wyjaśnić w sposób naturalistyczny.

McMullin, Stek, Van Till i Allen stanowczo sprzeciwiają się teologii Boga w lukach wiedzy - i słusznie. Ten tok rozumowania jest w najlepszym razie anemiczną i miałką odmianą półdeizmu, która działanie Boga umieszcza w lukach wiedzy naukowej. Ponadto jest on powiązany ze słabą i bezbarwną apologetyką, zgodnie z którą być może najważniejszym źródłem czy motywacją, by wierzyć w Boga, jest to, że są pewne rzeczy, których nauka obecnie nie potrafi wyjaśnić. Bynajmniej nie przypomina to tego, co naucza Pismo! Teologia Boga w lukach wiedzy nie ma nic wspólnego z poważnym teizmem chrześcijańskim. Uwidacznia się to ewidentnie (przynajmniej) w następujących cechach. Po pierwsze i najważniejsze, zgodnie z prawdziwym teizmem chrześcijańskim Bóg w Swoim stworzeniu działa stale, natychmiastowo, osobiście oraz bezpośrednio: stale podtrzymuje je w istnieniu i rządzi nim w sposób opatrznościowy. Bóg jest bezpośrednio aktywny we wszystkim, od Wielkiego Wybuchu począwszy, a na spadającym wróblu skończywszy. Dosłownie nic nie dzieje się bez Jego podtrzymującej woli. ${ }^{57}$ Po drugie, prawa przyrody nie są bynajmniej niezależne od Boga i możliwe, że najlepiej myśleć o nich jako o regularnościach cechujących środki, za pomocą jakich Bóg obchodzi się z rzeczami, które stworzył, lub jako o nierzeczywistych okresach warunkowych wolności Bożej. (Dlatego w przekonaniu, że przy pewnych okazjach Bóg może uczynić coś wbrew temu, co czyni zazwyczaj, na przykład wskrzesić kogoś lub przemienić wodę w wino, nie ma bynajmniej nic niestosownego.) Wobec tego cała interwencjonistyczna terminologia - mówiąca o Bogu interweniującym w przyrodzie, zaktócającym ją, wtracającym się w nią albo naruszającym prawa przyrody — stanowi element teolo-

\footnotetext{
${ }^{56}$ Nie zamierzam sugerować, że jeśli ktoś opowiada się za teologią Boga w lukach wiedzy lub jej broni, sam wierzy w Boga tylko, jak gdyby był hipotezą. To zupełnie inna kwestia.

${ }^{57} \mathrm{~W}$ dodatku większość średniowiecznych myślicieli chrześcijańskich domagała się także rozróżnienia rodzajów działania Boga. Każde działanie przyczynowe w świecie wymaga Jego zgody. W związku z tym powstają pewne problemy. Dla niektórych wymóg ten brzmi, jak gdyby doktryna ta była umotywowana nie tyle odpowiednimi świadectwami empirycznymi, ile prawieniem Bogu metafizycznych komplementów.
} 
gii Boga w lukach wiedzy, a nie poważnego teizmu. Zgodnie z tym ostatnim Bóg teraz i zawsze osobiście działa w przyrodzie, której istnienie przez cały czas zależy od bezpośredniego Bożego działania. Przeto nie ma i być nie może niczego takiego, jak Boska ,interwencja” w przyrodzie.

$\mathrm{Na}$ tym z grubsza biorąc polegają metafizyczne różnice pomiędzy teizmem chrześcijańskim a teologią Boga w lukach wiedzy. Ale są jeszcze równie ważne różnice epistemologiczne. Po pierwsze, według teizmu chrześcijańskiego myśl, że istnieje taka osoba jak Bóg, nie jest hipotezą postulowaną, aby wyjaśnić to czy owo. ${ }^{58} \mathrm{Nie}$ głosi również, że głównym powodem, by wierzyć w istnienie osoby, takiej jak Bóg, jest fakt, że istnieją zjawiska, które wymykają się wszelkim wysiłkom dzisiejszej nauki. ${ }^{59}$ Nasza wiedza o Bogu bierze się raczej z objawienia ogólnego, które przypomina coś w rodzaju Tomaszowej wiedzy ogólnej o Bogu albo Kalwinowskiego sensus divinitatis [zmysłu boskości], a także — co ważniejsze - z objawienia szczególnego danego w Piśmie oraz nauczania Kościoła na temat Bożego planu zaradzenia naszemu upadkowi w grzech.

Teologia Boga w lukach wiedzy jest przeto w każdym calu tak zła, jak sądzą McMullin, Van Till i Stek. (Faktycznie może być nawet gorzej niż myślą Van Till i Stek, ponieważ niektóre z ich poglądów — w szczególności ich odrzucenie koncepcji bezpośredniego działania Boga w przyrodzie - stanowią, jak sądzę, zdecydowany zwrot w stronę takiej teologii.) Poważni chrześcijanie, w rzeczy samej, powinni stanowczo odrzucać ten tok myślenia. Wspólnota chrześcijańska wie, że Bóg przez cały czas działa w stworzeniu, że prawa przyrody, jeśli jakieś istnieją, nie są niezależne od Boga, jak również to, że istnienie Boga z pewnością nie jest hipotezą sformułowaną, aby wyjaśnić to, z czym nauka sobie nie radzi. Ponadto wspólnota chrześcijańska rozpoczyna badania naukowe, już wierząc w Boga, nie angażuje się w nie (czy nie musi się w nie angażować) z powo-

\footnotetext{
${ }^{58}$ Por. mój artykuł: „Is Theism Really a Miracle?”, Faith and Philosophy 1986, vol. 3, no. 2, s. 132 i n. [109-134].

${ }^{59}$ Kolejny problem związany z tym tokiem myślenia polega na tym, że im więcej wyjaśnia nauka, tym węższy zakres działania Boga. Wiąże się to z niebezpieczeństwem zupełnego wykluczenia ze świata poprzez coraz większe nadwątlanie powodów, by (w ramach tego toku myślenia) wierzyć, że w ogóle istnieje osoba, taka jak Bóg. (Oczywiście z drugiej strony trzeba przyznać, że czasami rzeczy mają się zupełnie przeciwnie, na przykład współcześnie znacznie trudniej niż w czasach Darwina zrozumieć, jak to możliwe, że życie powinno powstać wyłącznie dzięki regularnościom odkrywanym przez fizykę i chemię.)
} 
dów apologetycznych czy to względem siebie, czy też tych, którzy nie są chrześcijanami. Oczywiście z tego wszystkiego w żadnym razie nie wynika, że chrześcijańska wspólnota naukowa powinna popierać naturalizm metodologiczny. Wspólnota ta stara się odpowiedzieć na następujące pytania: w jaki sposób najlepiej zrozumiemy Boże stworzenie, w jakim Bóg nas umieścił?; jaka jest najlepsza droga postępowania?; jakich informacji możemy lub będziemy używać? Czyż nie jest jasne, przynajmniej początkowo, w jaki sposób powinniśmy wykorzystać wszystko, co przydatne i pouczające, włączywszy to, co wiemy o Bogu i Jego relacji ze światem, oraz to, co wiemy dzięki objawieniu szczególnemu? Czyż nie możemy sensownie wnioskować na przykład, że Bóg stworzył życie albo człowieka lub cokolwiek innego drogą specjalnego stworzenia? (Nie twierdzę, że powinniśmy to wywnioskować. Twierdzę jedynie, że moglibyśmy i powinniśmy, jeśli silnie przemawiają za tym świadectwa empiryczne.) Czyż nie powinniśmy posłużyć się naszą wiedzą o grzechu oraz stworzeniu w psychologii, socjologii i w ogóle w naukach o człowieku? Czyż nie powinniśmy oceniać rozmaitych teorii naukowych za pomocą korpusu podstawowych przekonań, w którym zawiera się to, co wiemy o Bogu szczególnie jako chrześcijanie? Czyż nie powinniśmy decydować, co wymaga wyjaśnienia z perspektywy tego samego korpusu podstawowych przekonań?

No więc, dlaczego nie? Wstępnie wydaje się, że bez wątpienia jest to działanie racjonalne (próbując zrozumieć pewne zjawisko, powinno się wykorzystać całą posiadaną wiedzę), trudno sobie wyobrazić jakieś silne argumenty przeciwko temu. Takim postępowaniem z pewnością nie wikłamy się w żaden niefortunny tok myślenia charakterystyczny dla teologii Boga w lukach wiedzy. Czyniąc tak, nie jesteśmy tym samym zobowiązani do przyjęcia idei, że Bóg prawie w ogóle nie działa bezpośrednio w przyrodzie albo że Wszechświat jest jak olbrzymia maszyna, w działanie której Bóg mógłby interweniować jedynie z pewną trudnością. Nie jesteśmy zobowiązani również do przyjęcia idei, że jednym z głównych powodów wiary w Boga jest po prostu to, że są rzeczy, których nauka nie potrafi wyjaśnić, albo że idea Boga naprawdę jest czymś w rodzaju hipotezy o szerokim zakresie, postulowanej jedynie po to, by wyjaśnić te rzeczy. Nic podobnego. Tak naprawdę w obecnym kontekście cała kwestia teologii 
Boga w lukach wiedzy to zwykła zasłona dymna, która ma przesłonić sedno sprawy. ${ }^{60}$

\section{Dwa mocniejsze argumenty na rzecz naturalizmu metodologicznego}

Argumenty omówione powyżej nie są zbyt przekonujące. Jednak są także dwa zupełnie inne i, jak sądzę, znacznie mocniejsze argumenty czy rozumowania na rzecz przyjęcia naturalizmu metodologicznego w praktyce naukowej. Pierwszy z nich bez wątpienia zasługuje na osobny artykuł. Niestety, tutaj mogę zawrzeć tylko względnie zwięzłe jego omówienie.

\section{Nauka duhemowska}

Możemy omówić ten argument, dokonując analizy pewnych frapujących fragmentów książki Pierre'a Duhema, The Aim and Structure of Physical Theory[Cel i struktura teorii fizycznej]. ${ }^{61}$ Duhem był poważnym chrześcijaninem i poważnym naukowcem. Został (jak domniemywał) oskarżony przez Abla Reya o niestosowne przemycenie swoich chrześcijańskich poglądów metafizycznych i religijnych do swojej fizyki. ${ }^{62}$ Duhem odrzucił tę sugestię, twierdząc, że jego chrześcijaństwo nie wpływa nieodpowiednio na jego fizykę, ponieważ w żaden sposób do niej nie przenika. ${ }^{63}$ Sądził ponadto, że prawidłowy

\footnotetext{
${ }^{60}$ Co więcej, sądzę, że Newtonowi postawiono fałszywe oskarżenia. Sugerował on, że Bóg dokonuje okresowych korekt orbit planet. To prawda. Ale Newton nie zaproponował tego w charakterze racji, by wierzyć w Boga. Raczej było tak, że (oczywiście) Newton już był wierzący i nie mógł sobie wyobrazić żadnego innego wyjaśnienia ruchów planet. Okazało się, że był w błędzie. Jednak mógł mieć rację, a w każdym razie nie aprobował żadnej z idei charakterystycznych dla teologii Boga w lukach wiedzy.

${ }^{61}$ Por. Pierre M. Duhem, The Aim and Structure of Physical Theory, trans. Philip P. Wiener, Princeton University Press, Princeton 1954.

${ }^{62}$ Por. Abel Rey, „La Philosophie Scientifique de M. Duhem”, Revue de Métaphysique et de Morale 1904, t. 12, no. 4, s. 699 i n. [699-744].

${ }^{63}$ Por. dodatek do The Aim and Structure of Physical Theory, zatytułowany „Physics of a Believer", który stanowi przedruk odpowiedzi Reyowi. Tekst ten pierwotnie opublikowano w czasopiśmie Annales de Philosophie Chrétienne 1905, rocznik 77, seria 4, t. 1, s. 44 i n. oraz
} 
czy właściwy sposób dążenia do teorii fizycznej to sposób, w jaki faktycznie postępował: teoria fizyczna powinna być całkowicie wolna od jakiegokolwiek poglądu lub zaangażowania metafizycznego czy religijnego.

Duhem uważał tak z dwóch powodów. Po pierwsze, myślał, że religia ma niewielkie znaczenie dla teorii fizycznej: „,czy nie jest oczywistym faktem dla nas, jak dla wszystkich ludzi rozsądnych, że przedmiot i istota teorii fizycznej są obce doktrynom religijnym i nie mają z nimi żadnej styczności?" 64

Jednak tkwi tu coś jeszcze, coś przypuszczalnie głębszego. Chociaż Duhem mógł sądzić, że doktryny religijne mają niewiele wspólnego z fizyką, to bynajmniej nie sądził tak samo o doktrynach metafizycznych. W rzeczywistości był przekonany, że doktryny metafizyczne często wywierały głęboki wpływ na teorie fizyczne. Jak zauważył, wielu fizyków teoretyków uznało, że zasadniczym celem fizyki jest wyjaśnianie obserwowalnych zjawisk. Wyjaśnianie to trudna do uchwycenia kategoria i złożony proces. Jednak w tym wypadku owa wielka różnorodność form wyjaśniania sprowadza się do dostarczenia określonego ujęcia zjawisk, mówiącego o naturze czy budowie leżącej u ich podłoża rzeczywistości materialnej. Duhem następnie ilustruje tę tezę sugestywnymi przykładami, relacjonując szczegółowo, jak bardzo różnią się wyjaśnienia lub uzasadnienia zjawisk związanych z magnetyzmem, jakie formułowali atomiści, arystotelicy, zwolennicy Newtona czy kartezjanie. Atomiści udzielają niezbędnych wyjaśnien, postulując istnienie atomów, kartezjanie - czystych rozciągłości, zaś arystotelicy - materii i formy. ${ }^{65}$ Różnice pomiędzy tymi wyjaśnieniami, stwierdza Duhem, mają charakter metafizyczny. Odnoszą się do ostatecznej natury czy budowy materii. Lecz jeśli celem jest wyjaśnianie zjawisk za pomocą

133 i n.

(Przyp. tłum.) Przekład polski niemal w całości (pominięto przykłady z fizyki lub historii fizyki) ukazał się jako: Pierre DuнEm, „Fizyka wierzącego”, przeł. Monika Sakowska, w: Krzysztof Szlachcic (red.), Pierre Duhema filozofia nauki. Wybór pism, Wydawnictwo Uniwersytetu Wrocławskiego, Wrocław 1991, s. 51-72. Przedruk skróconego przekładu ukazał się w: Krzysztof Szlachсic, Filozofia nauk empirycznych Pierre'a Duhema, Wydawnictwo Uniwersytetu Wrocławskiego, Wrocław 2011, s. W96-W109.

${ }^{64}$ Pierre M. Duнem, „Physics of a Believer”, w: Duнem, The Aim and Structure..., s. 278 [273-311].

${ }^{65}$ Por. Duнem, The Aim and Structure..., s. 10-18. 
ostatecznej natury lub ukonstytuowania materii, to zasadnicze znaczenie ma prawdziwe ujęcie tej ostatniej - uzyskanie prawdziwej odpowiedzi na metafizyczne pytanie: ,jaka jest natura czy struktura materii?” W ten sposób, twierdzi Duhem, nauka podlega metafizyce: „Jeśli więc teorie fizyczne maja za cel wyjaśnienie praw doświadczalnych, to fizyka teoretyczna nie jest autonomiczna nauka, jest podporzadkowana metafizyce". ${ }^{66}$

Co więc jest nie tak? Problem, powiada Duhem, polega na tym, że jeśli myślimy o fizyce w ten sposób, to ocena wartości teorii fizycznej będzie zależeć od metafizyki, jaką przyjmiemy. Teoria fizyczna będzie zależna od metafizyki w ten sposób, że ktoś, kto nie akceptuje metafizyki związanej z daną teorią fizyczną, nie może zaakceptować również teorii. Problem ten polega na tym, że jeśli rozbieżności, od których roi się w metafizyce, przedostaną się do fizyki, to ta ostatnia nie może już być działalnością, w ramach której wszyscy możemy pracować wspólnie, nie zważając na nasze poglądy metafizyczne:

Uzależnienie teorii fizycznej od metafizyki na pewno nie jest środkiem, zapewniającym jej ogólną przychylność. [...] Jeżeli fizyka teoretyczna jest podporządkowana metafizyce, to podziały, kontrowersje między różnymi systemami metafizycznymi będą przenosiły się na teren fizyki. Teoria fizyczna uznana przez przedstawicieli jednej ze szkół metafizycznych za satysfakcjonującą, przez zwolenników innej szkoły zostanie odrzucona. ${ }^{67}$

Duhem cytuje dalej Christiaana Huygensa, który — jako „atomista” — odrzucił Newtonowską ideę oddziaływania na odległość: „dopóki sprawa dotyczy przyczyny pływów, jaką podał Pan Newton, jestem daleki od satysfakcji, nie czuję także zadowolenia z jego innych teorii, zbudowanych na podstawie jego zasady przyciągania, która jawi się mi jako absurd". ${ }^{68}$ Cytuje również komenta-

\footnotetext{
${ }^{66}$ Pierre DuHem, „Teoria fizyczna a wyjaśnianie metafizyczne”, przeł. Monika Sakowska, w: Szlachcic (red.), Pierre Duhema filozofia nauki..., s. 35 [32-36], przedruk w: SzlachCic, Filozofia nauk empirycznych..., s. W39 [W36-W40]. (Jest to przekład znacznej części rozdz. 1 w cz. I książki Duhema. Dla celów dydaktycznych pominięto przykłady z fizyki i historii fizyki - przyp. tłum.)

${ }^{67}$ Duнem, „Teoria fizyczna a wyjaśnianie...”, s. 35, przedruk w: Szlachcic, Filozofia nauk empirycznych..., s. W39.

${ }^{68}$ List Christiaana Huygensa do Georga W. Leibniza z dnia 18 listopada 1690 roku, w: Johannes Bosscha Jr. (ed.), Oeuvres Complètes de Christiaan Huygens, Correspondence 1685-
} 
rze Kartezjusza do dzieła Robervala, ${ }^{69}$ który wysunął teorię powszechnej grawitacji znacznie wcześniej od Newtona:

Całkowicie absurdalne jest założenie dodane do przytoczonego powyżej: autor przyjmuje, że pewna własność jest przyrodzona każdej części materii świata, a także, iż dzięki sile tej własności części te zmierzają ku sobie i wzajemnie się przyciągają. Zakłada również, że podobna własność tkwi w każdej części Ziemi, rozważanej względem innych części Ziemi, oraz że własność ta w żaden sposób nie porusza własności, która ją poprzedza. Aby to zrozumieć, musimy przyjąć nie tylko, że każda cząstka materialna jest ożywiona, a nawet ożywiona dużą liczbą rozmaitych dusz, które sobie nie przeszkadzają, lecz także, iż owe dusze cząstek materialnych są obdarzone wiedzą prawdziwie Boskiego rodzaju, bez żadnego medium wiedzą bowiem, co dzieje się w wielkiej odległości od nich, i stosownie do tego działają. ${ }^{70}$

Duhem zauważa, że jeśli fizyk teoretyk posługuje się metafizycznymi założeniami i pojęciami, których nie akceptują inni fizycy pracujący w tej dziedzinie, jeśli posługuje się nimi w taki sposób, że uniemożliwia to innym fizykom, którzy ich nie akceptują, aprobatę jego teorii powstałej na bazie tych założeń, to przynajmniej do tego stopnia ważna dla nauki współpraca między nimi będzie kuleć. Duhem proponuje zatem koncepcję nauki (zwłaszcza fizyki), w ramach której ta ostatnia jest niezależna od metafizyki:

[...] pozbawiłem doktryny metafizyczne prawa świadczenia zarówno za lub przeciw jakiejkolwiek teorii fizycznej. [...] wszystko to, co powiedziałem o metodzie, wedhug której postępuje fizyka, o naturze i zakresie możliwości, które należy przypisać teoriom tworzonym przez nią, nie przesądza nic o doktrynach metafizycznych, ani wierzeniach religijnych tego, który akceptuje moje stanowisko. Wierzący i niewierzący mogą zgodnie pracować nad postępem nauk fizycznych takich, jak je starałem się zdefiniować. ${ }^{71}$

1690, t. 9, Martinus Nijhoff, Den Haag 1901, list 2633, s. 538 [536-540] (cyt. za: DuнEм, The Aim and Structure..., s. 15).

${ }^{69}$ Por. Gilles Roberval, Aristarchi Samii, De mundi systemate, patribus et motibus ejusdem, liber singularis, książka niewydana drukiem, Paris 1643.

${ }^{70}$ List Kartezjusza do Mersenne'a z dnia 20 kwietnia 1646 roku, w: Paul TANnERY et Charles Adam (éd.), Oeuvres de Descartes, Correspondence Juillet 1643 - Avril 1647, t. 4, Léopold Cerf, Paris 1901, list CDXXX, s. 400-401 [396-403] (cyt. za: Dunem, The Aim and Structure..., s. 15-16 [Duhem błędnie odsyła do numeru listu i strony — przyp. thum.]). 
Mamy zatem kolejny argument na rzecz naturalizmu metodologicznego. Do tego jest prosty i zdroworozsądkowy: to ważne, abyśmy wszyscy — chrześcijanie, naturaliści, antyrealiści kreatywni (creative anti-realists), ktokolwiek mogli współpracować w fizyce i innych naukach. Dlatego w ramach ujęć naukowych nie powinniśmy posługiwać się zaangażowaniami i założeniami, jakie przyjmują tylko niektórzy z nas - to znaczy nie powinniśmy posługiwać się nimi w sposób, który czyniłby określony obszar nauki mniej akceptowalnym lub wręcz nie do przyjęcia dla kogoś, kto nie podziela danego zaangażowania czy założenia. ${ }^{72}$ Ale wówczas nie możemy posłużyć się (w ten sposób) ideami, takimi jak ta, że świat wraz z tym, co się w nim znajduje, został zaprojektowany i stworzony przez Boga. Nauka uprawiana w sposób należyty, o ile ma być wspólna dla nas wszystkich, będzie musiała wystrzegać się każdej zależności od poglądów metafizycznych i religijnych, które utrzymują tylko niektórzy z nas, dlatego powinniśmy przyjąć naturalizm metodologiczny. Oczywiście, aby uprawiać naukę duhemowską, nie musimy być naturalistami metafizycznymi, ale jeśli nauka ma być należycie uniwersalna, nie możemy się odwoływać do założeń lub zaangażowań, które nie są powszechnie podzielane.

Jest to atrakcyjny argument na rzecz naturalizmu metodologicznego. Ma on charakter pragmatyczny, nie zasadniczy: dobrze jest uprawiać naukę wspólnie, zatem powinniśmy maksymalizować możliwość współpracy i wspólnych badań, gdzie tylko się da. Dlatego w ramach nauki nie powinniśmy wysuwać teorii zasadniczo obejmujących przekonania, które nie są wspólne nam wszystkim.

Traktując teorię fizyczną jako hipotetyczne wyjaśnienie materialnej rzeczywistości, uzależniamy ją od metafizyki. Przez to, nie nadając jej formy, na którą mogłaby przystać największa liczba umysłów, ogranicza się jej akceptację do tych, którzy uznają głoszoną przez nią filozofię. ${ }^{73}$

\footnotetext{
${ }^{71}$ Duнем, „Fizyka wierzącego...”, s. 52, przedruk w: Szlachсіс, Filozofia nauk empirycznych..., s. W97.

${ }^{72}$ Oczywiście nie wykluczałoby to wykorzystania takich idei w teoriach zaproponowanych nie jako prawdziwe, ale jedynie adekwatne empirycznie.

${ }^{73}$ Pierre Duhem, „Teoria fizyczna i klasyfikacja naturalna”, przeł. Monika Sakowska, w: Szlachcic (red.), Pierre Duhema filozofia nauki..., s. 36 [36-44], przedruk w: Szlachcic, Filozofia nauk empirycznych..., s. W40 [W40-W49]. (Jest to przekład prawie całego rozdz. 2 w cz. I książki Duhema - przyp. tłum.)
} 
Powinniśmy więc przyjąć pewnego rodzaju pozytywistyczną (w starym sensie tego słowa), koncepcję nauki jako niezaangażowanej metafizycznie. Nauka uprawiana należycie nie przyjmuje metafizycznych lub religijnych założeń ani nie ma metafizycznych lub religijnych konsekwencji.

Ta prostota jest nieco zwodnicza. Tym, co naprawdę ważne dla wspólnotowości, nie jest brak w nauce hipotez odnoszących się do Boga lub metafizyki jako takiej ani innych idei filozoficznych, lecz raczej nieobecność poglądów czy założeń, które nas dzielą. Jeśli istnieją określone poglądy metafizyczne, które wszyscy podzielamy, to z tego punktu widzenia nie ma żadnego powodu, by zakazać ich w nauce. (Zatem powód, dla którego Duhem uznał, że nauka powinna powstrzymać się od metafizyki, jest całkiem inny od tego, jaki przyświeca Basowi van Fraassenowi, chociaż ich poglądy są zbliżone.) Z sugestii Duhema wynika, że nauka może posłużyć się dowolną powszechnie przyjętą propozycją lub założeniem, nawet jeśli $\mathrm{w}$ istocie jest to część metafizyki lub teologii. ${ }^{74}$ Być może, przynajmniej pod pewnymi względami, przyjęcie, że przeszłość faktycznie się wydarzyła lub że przedmioty materialne istnieją niezależnie od myśli człowieka, ma charakter metafizyczny. Jeśli są to założenia, które my wszyscy lub prawie wszyscy przyjmujemy, to $\mathrm{z}$ tej perspektywy mogą zostać włączone do nauki.

Jakiego rodzaju sądy przyjmuje niemal każdy uczestnik działalności naukowej? Dostrzegamy tu ogniwo łączące Duhema i van Fraassena - a także oczywiście związek $\mathrm{z}$ ideą, że nauka ma charakter empiryczny: nauka w pewien szczególny sposób wiąże się z werdyktem doświadczenia, w szczególności werdyktem doświadczenia zmysłowego. Problem danych empirycznych nie jest jednak głównym zagadnieniem, co do którego się nie zgadzamy. Jest wiele do powiedzenia w tej sprawie, ale brak tu na to miejsca. Powiem więc tylko rzecz następującą. Być może obserwacja, jak wielu nam mówiło, w pewnym sensie jest „obciążona teoretycznie”, ale nie wynika z tego, że jest obciążona teoretycznie aż tak, by zniszczyć wspólnotowość. Wyjąwszy wyjątkowe okoliczności, prawdopodobnie wszyscy zgodzimy się, że wskazówka znajduje się pomiędzy 5 a 6

\footnotetext{
${ }^{74}$ Nie jest dla mnie jasne, czy sam Duhem proponował, aby fizyka nie zawierała żadnej metafizyki, czy też uznawał jedynie, że fizyka nie powinna zawierać metafizyki stwarzajacej podziały. Często pisał tak, jak gdyby chodziło mu o pierwszą z wymienionych możliwości, ale jego argumenty wspierają tylko tę drugą.
} 
(nie zaś, dajmy na to, 1 a 2). Dalej, teoria, którą obciążona jest obserwacja, nie musi nas dzielić w każdym wypadku. Ponadto nawet tam, gdzie teoria rzeczywiście nas dzieli (przykładowo tam, gdzie realista twierdzi, że widzi ślad elektronu w komorze Wilsona, a empirysta nie widzi niczego takiego), przywiązywanie należytej wagi do sposobu, w jaki termin, taki jak ,widzieć”, na mocy analogii zostaje rozszerzony, często może wyeliminować rzekomy brak zgody co do tego, co jest widziane.

Więc sądy, których prawdziwość da się określić na podstawie obserwacji, znajdą się pośród tych, które z tej perspektywy są dopuszczalne w nauce. Oczywiście nauka wykorzystuje znacznie więcej: posługuje się również werdyktem rozumu, logiką i matematyką - których, powtórzmy, brak zgody dotyczy w niewielkim stopniu. W nauce szeroko akceptuje się jeszcze inne sądy, chociaż ich prawdziwości nie da się określić przez obserwację, sądy te wykraczają także poza logikę i matematykę. Uznajemy za sensowne założenie, że regularności obowiązujące w naszym obszarze kosmosu obowiązują również w rejonach czasoprzestrzennie znacznie od nas odleglejszych. Przyjmujemy, że przyszłość w nadzwyczaj trudny do wyrażenia, niemniej rzeczywisty sposób będzie podobna do przeszłości. (Nie czujemy się zobowiązani do powtórzenia eksperymentu nazajutrz z powodu tego, że nocą coś mogło się zmienić.) Przyjmujemy także, iż prawdopodobnie będą obowiązywały rozmaite zasady indukcyjne, że należy preferować wyjaśnienia proste (ponownie w sensie, który nadzwyczaj trudno wyjaśnić) nad złożone i tak dalej.

W świetle tego atrakcyjnego duhemowskiego ideału nauka ma być przedsięwzięciem wspólnotowym oraz stosować (w sensie wspomnianym powyżej) wyłącznie sądy, które podzielają wszyscy lub prawie wszyscy, którzy biorą w nim udział. Nauka duhemowska, można by rzec, byłaby nauką publiczna, maksymalnie globalną i całkowicie neutralną w odniesieniu do różnic światopoglądowych. Oczywiście istnieją rozległe obszary naszej ekonomii poznawczej, gdzie te rozważania światopoglądowe faktycznie są całkowicie nieistotne. Każdy, kto ma w miarę dobry wzrok, dostrzeże, iż wskazówka pokazuje 7, metafizyczne lub teologiczne różnice nie mają tu nic do rzeczy. Prawdopodobnie to samo tyczy się pomiaru odległości Ziemi od Jowisza. Każdy zrozumie, że sprzeczność nie może być prawdziwa. Nie ma także znaczenia, czy jesteś teistą, antyrealistą, naturalistą, czy kimkolwiek innym. Tak samo będzie w przypadku wydeduko- 
wania twierdzenia Cantora z aksjomatów zwykłej teorii mnogości. (Oczywiście może rozgorzeć spór o same aksjomaty.)

Nauka duhemowska w sposób oczywisty obejmowałaby naturalizm metodologiczny: żadne hipotezy odnoszące się do Boga lub grzechu, bądź tego, co wiadomo dzięki objawieniu szczególnemu, zasadniczo nie wchodzą w zakres takiej nauki. Jednak decydujące znaczenie ma tu dostrzeżenie, że naturalizm metodologiczny będzie stanowił tylko niewielki fragment bardziej globalnego ograniczenia: tak pojęta nauka nie tylko nie zastosuje hipotez dotyczących Boga, lecz także żadnych hipotez, których siła przekonywania pociąga za sobą lub presuponuje naturalizm metafizyczny. Nie przyjmie także na przykład założeń podobnych do tych, na jakich najprawdopodobniej zasadza się znaczna część kognitywistyki. Przykładowo nauka duhemowska nie może w prawidłowy sposób przyjąć, że dualizm psychofizyczny jest fałszywy albo że ludzie są przedmiotami materialnymi - są to założenia metafizyczne, które nas dzielą. Nie będzie mogła wykorzystać również deterministycznych założeń leżących u podstaw znacznej części nauk społecznych. Również te przekonania istotnie nas dzielą. Dalej, trzeba będzie zakazać wielu założeń o właściwym funkcjonowaniu istot ludzkich: na przykład Simonowskich założeń o tym, co jest, a co nie jest racjonalne, oraz twierdzeń Piageta o tym, w co uwierzą, a w co nie uwierzą prawidłowo funkcjonujące dwunastolatki, albo szeroko rozpowszechnionego w religioznawstwie założenia, że autentyczne przekonania religijne muszą być objawem patologii lub nieprzezwyciężalnej ignorancji. Nauka duhemowska zakazywałaby także idei, że Teoria Wspólnego Pochodzenia ma charakter pewny, oraz idei rozpowszechnianej przez autorów piszących o ewolucji: że losowy lub przypadkowy charakter zmienności genetycznej wyklucza możliwość, że ludzie zostali zaprojektowani - przez Boga lub kogokolwiek innego. Taka nauka wykluczałaby też McMullinowską Zasadę Obojętności i być może znacznie więcej — na przykład niektóre zasady psychologii, socjologii, ekonomii i tak dalej. $Z$ tego powodu zamiast mówić o „naturalizmie metodologicznym”, powinniśmy mówić raczej o „neutralizmie metodologicznym”, a może „neutralizmie metafizycznym".

Nauka duhemowska jest przeto maksymalnie globalna. Możemy uprawiać ją wspólnie i uzgadniać jej rezultaty. Ale co z tymi, którzy, jak na przykład Simon, sądzą, iż ważne jest również uprawianie nauk o człowieku w taki sposób, 
że punktem wyjścia jest nie naturalizm metodologiczny, lecz metafizyczny? Co z tymi, którzy podobnie jak atomiści, kartezjanie czy arystotelicy sądzą, że ważne jest uprawianie nauki takiego rodzaju, której celem jest wyjaśnianie zjawisk za pomocą kryjących się za nimi nieobserwowalnych rzeczywistości? Co z chrześcijanami lub teistami, którzy proponują badanie ludzkiej rzeczywistości przy uwzględnieniu wszystkiego, co wiedzą, włączywszy to, co wiedzą jako chrześcijanie lub teiści? W zgodzie z twierdzeniami Duhema w żadnym z powyższych przypadków nie ma nic niewłaściwego. Czy powinniśmy działalność tego rodzaju nazywać „nauką”? Czy zasługuje na to zaszczytne miano? U Duhema nie ma żadnego powodu, by udzielić odpowiedzi negatywnej. Ważne, abyśmy dostrzegli, że nauka tego rodzaju nie jest nauką duhemowska i nie rości sobie prawa do powszechnej aprobaty, jaką cieszy się ta ostatnia. Ale oczywiście nie jest to żaden zarzut wobec niej. Dlatego zgodnie z pełniejszą duhemowską wizją wszyscy pracowalibyśmy wspólnie w ramach nauki duhemowskiej, a każda spośród zainteresowanych grup — na przykład naturaliści i teiści, a być może również inni - mogliby następnie włączać naukę duhemowską w pełniejszy kontekst, obejmujący zasady metafizyczne lub religijne, specyficzne dla każdej grupy. Nazwijmy tę szerszą koncepcję nauki „nauką augustiańską”. Oczywiście motywacja po temu będzie się bardzo różnić w poszczególnych dziedzinach. Fizyka i chemia mają charakter zdecydowanie duhemowski ${ }^{75}$ (oczywiście to samo może nie być prawdą w filozofii fizyki) — możliwe, że tam nauka augustiańska okazałaby się w przeważającej mierze bezcelowa. To samo dotyczy nauk biologicznych: niewątpliwie znaczną część tego, co się tam dzieje, można uznać za naukę duhemowską. $Z$ drugiej strony w tym obszarze znajdują się również elementy nieduhemowskie, takie jak wspomniane wcześniej deklaracje pewności oraz twierdzenia, że biologia ewolucyjna wykazuje, że człowieka i inne formy życia trzeba postrzegać jako rezultat przypadku (a więc nie można sądzić, że zostały zaprojektowane). Jednak w naukach o człowieku rozległe obszary są wyraźnie nieduhemowskie. To właśnie w tych dziedzinach nauka augustiańska byłaby najwłaściwsza i najdonioślejsza.

\footnotetext{
${ }^{75}$ Zasada Obojętności (por. powyżej, s. 23-24) nie ma charakteru duhemowskiego, ale niełatwo wskazać jakieś inne przykłady tego typu. (Zakładam, że interpretacje mechaniki kwantowej — w przeciwieństwie do niej samej — należą raczej do filozofii niż fizyki.)
} 
Powróćmy więc do naszego najważniejszego pytania: czy chrześcijańska wspólnota naukowa powinna przestrzegać ograniczeń naturalizmu metodologicznego? Tam, gdzie obowiązuje ten argument, odpowiedź brzmi: tak, naturalnie - w dziedzinach, w których nauka duhemowska jest możliwa i wartościowa. Lecz nic nie wskazuje na to, że chrześcijańska wspólnota naukowa nie powinna także zajmować się, niemającą charakteru duhemowskiego, nauką augustiańską tam, gdzie jest to stosowne. Nie ma tu niczego, co sugerowałoby, że „jeśli coś nie ma charakteru duhemowskiego, to nie jest nauką".

\section{Hamulce nauki?}

Jest jeszcze inny argument na rzecz naturalizmu metodologicznego. Ten również cechuje się zdroworozsądkową prostotą. Bóg stworzył cały ten nasz cudowny (wonderful) i budzący podziw ( $a w f u l$ ) świat (oba słowa wzięte w ich etymologicznym sensie). Jedną z rzeczy, jakich chcemy dokonać jako stworzenia Boże, jest zrozumienie świata, który stworzył Bóg, zrozumienie (w takim stopniu, w jakim potrafimy), jak jest zbudowany, jaka jest jego struktura, w jaki sposób funkcjonuje. Oczywiście nie jest to jedyna rzecz, jaką dzieci Boże muszą robić ze światem, musimy również cenić go, dbać o niego, kochać, dziękować Panu za stworzenie go i widzieć w nim Jego rękę. Zrozumienie świata jest cenne, takie jest również zrozumienie go w sposób teoretyczny. Jeden ze sposobów zrozumienia czegoś polega na zobaczeniu, jak to jest zrobione, z czego się składa i w jaki sposób działa. Właśnie tym zajmują się w naukach przyrodniczych. Przedmiotem nauki jest przyroda. Dla chrześcijan celem (jednym z wielu) jest zrozumienie struktury i funkcjonowania tego świata. Jest to jeden ze sposobów docenienia Boskiego stworzenia, którego część stanowi poznanie Bożego obrazu i podobieństwa, na jakie zostaliśmy stworzeni.

Jednak nie zajdziemy w tej dziedzinie daleko, jeśli na pytanie, dlaczego to a to działa właśnie tak, jak działa?; albo jakie jest wyjaśnienie tego a tego? będziemy systematycznie i często odpowiadać: „bo Bóg tak to uczynił” albo „bo Bogu się tak podobało, więc tak być powinno”. Często będzie to odpowiedź prawdziwa, ${ }^{76}$ lecz nie tego typu odpowiedzi oczekujemy. Obejdzie się bez mó-

\footnotetext{
${ }^{76}$ Jednak nie zawsze. Jeśli pytanie brzmi: „dlaczego doszło do czegoś takiego, jak II wojna światowa?”, odpowiedzią nie będzie: „bo Bóg chciał tak uczynić”. Oczywiście Bóg pozwolit, by
} 
wienia, że Bóg w ten czy inny sposób spowodował, że Wszechświat ma takie, a nie inne właściwości. Ale tym, co chcemy poznać dzięki nauce, są odpowiedzi na pytania, takie jak: ,z czego to jest?”; ,jaka jest tego struktura?”; ,jak rzeczywiście to działa?”; „w jaki sposób łączy się to z innymi częściami Bożego stworzenia?" Twierdzenia, z których wynika, że Bóg dokonał tego czy owego (stworzył życie lub człowieka) bezpośrednio, w pewnym sensie są hamulcami nauki (science stoppers). Jeśli twierdzenie to jest prawdziwe, to prawdopodobnie nie możemy już zdobywać dalszej wiedzy o tym, w jaki sposób coś powstało, albo w jaki sposób zachodzi badane zjawisko. Jeśli bowiem Bóg dokonał czegoś bezpośrednio, to nie pozostaje już nic więcej do odkrycia. Jak to się dzieje, że istnieje coś takiego, jak światło? No cóż, Bóg powiedział: „niech stanie się światło" i stało się światło. To oczywiście prawda o olbrzymim znaczeniu, lecz na gruncie nauki jest nieprzydatna, nie pomaga bowiem dowiedzieć się więcej na temat światła: jaka jest jego fizyczna charakterystyka, jaki ma związek z innymi rzeczami i tak dalej. Przypisywanie czemuś bezpośredniego działania Boga skłania do zaniechania dalszych badań.

Oczywiście jest to argument na rzecz jedynie $c z e ̨ s ́ c i$ naturalizmu metodologicznego. Jest kilka różnych dróg, jakimi chrześcijaństwo może wniknąć w strukturę nauki: (1) przez stawianie i stosowanie hipotez, zgodnie z którymi Bóg działa bezpośrednio, lecz także (2) przez stawianie i stosowanie hipotez, zgodnie z którymi Bóg działa pośrednio; ale też (3) poprzez ewaluację teorii względem wiedzy podstawowej, która zawiera także teizm chrześcijański; ponadto (4) przez bezpośrednie lub pośrednie odwoływanie się do sądów, takich jak ludzie zostali stworzeni na obraz i podobieństwo Boga, oraz (5) przez bezpośrednie lub pośrednie odwoływanie się do sądów dotyczących doktryn, takich jak grzech pierworodny, które $\mathrm{w}$ ogóle nie wiążą się z żadną bezpośrednią wzmianką o Bogu, wreszcie (6) przez rozstrzyganie, co wymaga wyjaśnienia z punktu widzenia wspomnianej już wiedzy podstawowej. Rozważania przytoczone w akapicie wyżej w najlepszym razie stanowią argument za zakazaniem (1).

Ale rozważania te w ogóle nie stanowią argumentu za takim zakazem. Na przykład twierdzenie, że Bóg stworzył życie bezpośrednio, może być hamulcem

wybuchła II wojna światowa, ale bynajmniej nie był z tego zadowolony. 
nauki: nie wynika stąd jednak, że Bóg nie stworzył życia bezpośrednio. Nie mamy, rzecz jasna, żadnej gwarancji, że Bóg dokonał wszystkiego, posłużywszy się przyczynami wtórnymi lub w taki sposób, by zainspirować dalsze badania naukowe, pobudzić naszą naukową ciekawość albo z myślą o National Science Foundation. Oczywiście nie możemy rozsądnie przyjąć z góry, że wszystko, na co się natkniemy, ma zostać wyjaśnione za pomocą czegoś innego, co Bóg stworzył, bo niektórych rzeczy musiał dokonać bezpośrednio. Warto byłoby dowiedzieć się, jeśli to możliwe, jakich rzeczy dokonat bezpośrednio, ponieważ stanowiłoby to ważną część autentycznej i gruntownej wiedzy o Wszechświecie. To, że takie twierdzenia stanowią hamulce nauki, oznacza, że nigdy nie będą przydatne jako ogólna zasada. Nie oznacza to jednak, że nigdy nie są prawdziwe ani że nigdy nie będą mogły stanowić części rzetelnej teorii naukowej. (Oczywiście w ogóle nie wpływa to także na inne sposoby, w jakie chrześcijaństwo lub teizm chrześcijański mogą mieć znaczenie dla nauki.) Zdanie sobie sprawy, że twierdzenia o bezpośrednim Boskim działaniu są hamulcami nauki, nie jest równoważne domaganiu się, aby nauka musiała udawać, że stworzony Wszechświat po prostu istnieje, odmawiając uznania, iż naprawdę został stworzony, co stanowiłoby wielki, nieuzasadniony krok.

Zatem niewiele przemawia na rzecz naturalizmu metodologicznego. W najlepszym razie mówi on nam jedynie, że nauka duhemowska musi być metafizycznie neutralna oraz że twierdzenia o bezpośrednim działaniu Boga zwyczajnie nie będą sprzyjać dobru nauki. A nawet w tych dwóch wypadkach możemy co najwyżej twierdzić, że naturalizm metodologiczny to nie pryncypialny zakaz, lecz ogólne zalecenie, które w pewnych okolicznościach wyraźnie nie znajduje zastosowania. Nie ma żadnego powodu, by zakazać pytań, takich jak: „czy Bóg stworzył życie bezpośrednio?" Nie ma żadnego powodu, dlaczego takiego zagadnienia nie badać empirycznie. ${ }^{77}$ Nie ma również żadnego powodu, by odgórnie zakazywać odpowiedzi twierdzącej.

\footnotetext{
${ }^{77}$ Dlaczego naukowiec nie mógłby myśleć następująco: Bóg stworzył świat, a oczywiście wszystko w nim stworzył bezpośrednio lub pośrednio? Po przeprowadzeniu wielu badań nie rozumiemy, jak stworzył zjawisko Z (na przykład życie) w sposób pośredni, dlatego prawdopodobnie stworzył je w sposób bezpośredni.
} 
Myśl chrześcijańska (w szczególności od dojrzałego średniowiecza) w przeciwieństwie do greckiej (a w szczególności myśli Arystotelesowej) ${ }^{78}$ ma silną tendencję do postrzegania świata jako bytu na wskroś przygodnego. Świat nie musiał zaistnieć, to znaczy Bóg nie musiał go stworzyć. Świat nie musiał otrzymać właśnie tej struktury, jaką posiada, to znaczy Bóg mógł stworzyć świat inny od naszego. To poczucie przygodności przyrody stało się ważnym źródłem podkreślania empirycznego charakteru nauki nowożytnej. W charakterze pewnego rodzaju niepisanej, roboczej zasady, możemy powiedzieć, że dzięki rozumowi, myśleniu apriorycznemu poznajemy to, co nie może być inne niż jest. Zaś dzięki zmysłom, dzięki badaniu aposteriorycznemu poznajemy to, co przygodne. ${ }^{79}$ Ale świat, który Bóg stworzył, jest pełen przygodności. Dlatego nie ograniczamy się do siedzenia $\mathrm{w}$ fotelach i rozmyślania o świecie, próbując z pierwszych zasad wywnioskować, ile zębów znajduje się w końskim pysku, lecz zamiast tego po prostu tam zaglądamy. To samo powinno tyczyć się pytania, jak Bóg działa w świecie: powinniśmy tu mniej polegać na apriorycznej teologii, a więcej na empirycznym badaniu. Nie mamy żadnych dobrych podstaw, by nalegać, że Bóg musi postępować w jeden określony sposób. O ile bowiem nam wiadomo, Bóg jest całkowicie wolny w Swoim działaniu. Być może stworzył życie ludzkie drogą specjalnego stworzenia lub tą drogą stworzył inne rzeczy. Nie możemy odgórnie całkowicie tego wykluczyć, odwołując się do spekulatywnej teologii. Powinniśmy to sprawdzić.

Zatem istotę mojego wywodu można podsumować następująco. Wedle Augustyna, Kuypera i wielu innych historię człowieka zdominowała walka, rywalizacja pomiędzy Civitas Dei a Miastem Człowieka. Zadanie chrześcijańskiej

\footnotetext{
${ }^{78}$ Por. Arystoteles, Analityki wtóre, I, 1-2, 4 (wydanie polskie: Arystoteles, Analityki pierwsze i wtóre, przeł. Kazimierz Leśniak, Biblioteka Klasyków Filozofii, PWN, Warszawa 1973), gdzie Arystoteles deklaruje, że scientia polega na postrzeganiu tego, co w sposób konieczny wynika z czegoś, co uznaje się za koniecznie prawdziwe. (Oczywiście postępowanie Arystotelesa nie zawsze dobrze pokrywa się z tą sugestią.)

${ }^{79}$ Oczywiście w najlepszym razie to przybliżona i ogólna charakterystyka: możemy w oczywisty sposób poznawać aposteriorycznie to, co konieczne (na przykład za pomocą komputerów udowadniać skomplikowane twierdzenia), a być może także poznawać apriorycznie to, co przygodne. Zagadnienie związku między tym, co aprioryczne, a koniecznością, z jednej strony, oraz między przygodnością a tym, co aposterioryczne, z drugiej (kwestia relacji między rozróżnieniem a priori/a posteriori oraz rozróżnieniem konieczne/przygodne), jest równie głębokie, jak fascynujące.
} 
wspólnoty akademickiej częściowo polega na poznaniu granic i rysów tej rywalizacji, aby dostrzec, jak rozgrywa się ona na tle życia intelektualnego w ogóle, a także na zajmowaniu się rozmaitymi dziedzinami życia intelektualnego jako obywatele Civitas Dei. To naturalnie sugeruje uprawianie nauki przy uwzględnieniu wszystkiego, co wiemy: tego, co wiemy o Bogu, tego, co wiemy o Jego stworzeniu, tego, co wiemy dzięki wierze, a także tego, co wiemy z innych źródeł. Tej naturalnej sugestii zakazuje Zasada Naturalizmu Metodologicznego. Jednak pomimo, że naturalizm metodologiczny jest powszechnie przyjmowany, wręcz z egzaltacją, niewiele za nim przemawia. Argumenty za takim naturalizmem przebadane na chłodno, kiedy wszystko widzi się dokładniej, okazują się naprawdę słabe. Dlatego powinniśmy odrzucić naturalizm metodologiczny, pojmowany w jego pełnej ogólności. Może powinniśmy dołączyć do innych w ramach nauki duhemowskiej, ale powinniśmy uprawiać również naszą własną naukę augustiańską.

Na zakończenie zwrócę uwagę na jeszcze jedną wypowiedź Johna Steka:

Teologia musi wziąć pod uwagę wszystko, czego ludzkość dowiedziała się o świecie, a nauka musi w równym stopniu wziąć pod uwagę wszystko, czego dowiedzieliśmy się o Bogu. Nie możemy w gruncie rzeczy uprawiać teologii, nie zaprzeczywszy naszej istocie oraz powołaniu na namiestników świata, nie badając wszystkiego, co wiemy o świecie. Nie możemy również, bez zaprzeczenia naszej istocie oraz powołaniu na namiestników świata, uprawiać nauki, nie badając zarazem wszystkiego, co wiemy o Bogu. ${ }^{80}$

I w tym właśnie rzecz.

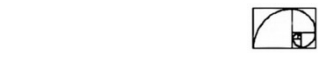

Alvin Plantinga

\section{Methodological Naturalism?}

\section{Summary}

The philosophical doctrine of methodological naturalism holds that, for any study of the world to qualify as "scientific", it cannot refer to God's creative activity (or any sort of divine activity). The methods of science, it is claimed, "give us no purchase" on theological

\footnotetext{
${ }^{80}$ Sтек, ,What Says the Scripture...”, s. 260-261.
} 
propositions - even if the latter are true - and theology therefore cannot influence scientific explanation or theory justification. Thus, science is said to be religiously neutral, if only because science and religion are, by their very natures, epistemically distinct. However, the actual practice and content of science challenge this claim. In many areas, science is anything but religiously neutral; moreover, the standard arguments for methodological naturalism suffer from various grave shortcomings.

The philosophical doctrine of methodological naturalism is flawed. Furthermore, neither claims about the definition or essential nature of science, nor theological presuppositions (e.g., "functional integrity"), can properly support methodological naturalism. However, one may find stronger support for the doctrine in what might be called "Duhemian science" - i.e., those empirical inquiries pursued by all parties on common ground, independently of whatever metaphysical assumptions may be held by only some investigators. Duhemian science is thus "maximally inclusive". "Augustinian science", on the other hand, may employ particular theological or philosophical assumptions. The ideal of Duhemian science should not exclude Augustinian science: both are valid forms of inquiry.

Keywords: methodological naturalism, metaphysical naturalism, Christian theism, religious non-neutrality of science, God-of-the-gaps theology, Duhemian science, Augustian science.

Słowa kluczowe: naturalizm metodologiczny, naturalizm metafizyczny, teizm chrześcijański, religijna nieneutralność nauki, teologia Boga w lukach wiedzy, nauka duhemowska, nauka augustiańska. 